\title{
A STUDY IN CONSTITUTIONAL RIGIDITY. I
}

\author{
Charles V. LaughitN*
}

$\mathrm{I}$ T IS the purpose of this essay to show how the amendment of state constitutions in several states ${ }^{\mathrm{I}}$ has been hampered by provisions requiring that a proposed amendment must be ratified by a majority of the electors voting for any purpose at the general election at which the proposed amendment is submitted. Most state constitutions require only that the votes favorable to a proposed amendment exceed those against it. They disregard all who vote in a general election ${ }^{2}$ at which a proposed amendment is submitted, but do not vote either for or against the amendment in question. The difference in the two systems of amendment is not always apparent from a perusal of the text of constitutional provisions, but subtle differences in terminology are often attended by substantial consequences. ${ }^{3}$ The states which have faulty systems of amending their constitutions are Illinois, Minnesota, Mississippi, Oklahoma, Tennessee, and Wyoming.

Amendments may be proposed either by legislatures or by constitutional conventions. ${ }^{4}$ More states require that a majority of those voting at a general election be obtained in order to call a convention than require such a majority to approve a legislatively proposed amendment. The count is eighteen to six.s ${ }^{5}$ Our chief concern, however, will be with the

* Member of the Illinois and District of Columbia bars, now serving in the armed forces. Owing to Mr. Laughlin's inability to revise and bring these materials up to date, Professor K. C. Sears of the University of Chicago Law School has contributed considerably in the final preparation of this article.

${ }^{2}$ Fortunately this number is not great and has decreased during the past fifty years.

2 By voting upon candidates for office, or by voting for or against other proposals.

3 Appendix A sets forth the citations of the sections of all state constitutions which deal with amendment. In Appendix $B$ an attempt is made to analyze and classify the various systems by which state constitutions are amended. These appendices will appear following the last installment of this article.

4 See Appendix B. Proposal by initiative petition is not considered in this immediate connection.

5 Ibid. It is to be noted, however, that very few states (apparently only two) are so rigid as regards the approval of the amendments, or the new constitution, that is submitted by a constitutional convention. Generally a special election may be held for such a purpose, and in this special election only those interested in voting upon the constitutional proposals will vote. This appearance of flexibility may be illusory when it is considered that sometimes a proposed constitution is submitted to the electorate as an entirety, and a few unpopular sections may secure the defeat of the entire document. Cf. Sears, Horse and Buggy Government, Chicago Sunday Times, p. 6 M. (April 30, I939), as regards the proposed Tllinois Constitution of I922. 
ratification of amendments proposed by legislative assemblies, rather than with the call of constitutional conventions.

Five of the six states which require a majority of all those voting for any purpose at a general election to ratify a proposed constitutional amendment also have the same requirements as regards the call of a constitutional convention. On the other hand, of the eighteen states which require a majority of all votes cast for any purpose at a general election to call a convention, thirteen permit ratification of a legislatively proposed amendment by a majority of the votes cast on that amendment. A study of the amendment experience of this larger group of eighteen states would be complicated by the fact that in thirteen of them an easier method of amending the constitution exists, whereas that is not true of the smaller group of states. The American people seem generally to have preferred the proposal of constitutional amendments by state legislatures over the use of constitutional conventions. This study will not be limited, however, to those states which now require a majority of all votes cast at a general election to ratify an amendment, but will include five additional states $^{6}$ which, though formerly employing that system, have either by formal amendment or by judicial interpretation adopted the system more generally used.

The requirements for constitutional amendment in some states are clearly apparent from the language of the constitutions themselves, but in other states the amending provisions of their constitutions are unclear and ambiguous. In some states it is clearly evident that an amendment need only obtain a majority of the votes cast upon the particular amendment. ${ }^{7}$ In other states it is manifest that the constitution was intended to require a majority of those voting for any purpose at a general election. $^{8}$ There are still other states, however, the meaning of whose constitutions is far less apparent. The constitutions of Idaho, Indiana, and Wyoming provide that a proposed amendment must be approved by a "majority of electors." It has been pointed out" that such language is

${ }^{6}$ Alabama, Arkansas, Indiana, Nebraska, and Ohio.

7 For example, in Iowa it is specified that an amendment, to be approved, must be voted upon affirmatively by a "majority of the electors voting thereon."

${ }^{8}$ For example, in Minnesota it is provided that to become effective an amendment must be approved by "a majority of all the electors voting at said election." Before 1898 a proposed amendment could be ratified in Minnesota by a majority vote thereon. In that year the method of amending the constitution was amended and the above language adopted. Without question the legislature, in proposing this amendment to the amending process, intended to restrict future amendments to such as might be adopted by a majority of all votes cast at a general election. See Anderson, The Need for Constitutional Revision in Minnesota, Ir Minn. L. Rev. I89, I92, I93 (I927).

9 Chattin, In re Todd and Constitutional Amendment, so Ind. L. J. 5 Io (I935). 
susceptible of three interpretations: I) that a majority of all of the qualified voters in the state is required; 2) that a majority of those voting for any purpose at the election at which the amendment is submitted must be obtained; and 3) that a majority of those voting upon the amendment is sufficient.

Every one of these constructions enjoys judicial sanction. The first finds possible support in a Wyoming case. ${ }^{\mathrm{x}}$ The previous $^{\mathrm{II}}$ leading case in Indiana, State v. Swift, took the same position. ${ }^{\mathbf{x}}$ In the cases following the Swift case $^{\mathrm{x}} 3$ this theory is qualified by saying that, in the absence of actual evidence in the record, the majority of those voting at an election would be regarded as the majority of the electorate. Such a presumption seems, for the cases without such evidence, to announce as a rule of law the second of the three interpretations rather than the first. The Idaho constitution is worded the same as those of Wyoming and Indiana, but in Idaho the third of the three constructions was reached. ${ }^{\text {I4 }}$ The court reversed an administrative ruling that an equal suffrage amendment was defeated because it failed to obtain a majority of all votes cast for any purpose at the election. The court placed its decision upon the basis of practicality, pointing out that the administrative interpretation of the constitution would render amendment too difficult. If an analytical basis were needed to support the decision, it could be argued that the term "electors" refers as reasonably to those voting upon a particular question as it does to the total number of eligible voters or to the total number of

Io State ex rel. Blair v. Brooks, I7 Wyo. 344, 99 Pac. 874 (Igo8). Prior to that case the Wyoming Constitution had been administratively construed to require only a majority of those voting upon the issue. See Dodd, The Revision and Amendment of State Constitutions I86 (I9ro). The court realized that this task of ascertaining the size of the electorate, that is, all those eligible to vote, is one of great difficulty, but passed that problem as not involved in the case. The case was one in which 12,160 votes were cast for a proposed amendment and $\mathrm{I}, 363$ against it. Since $37,65 \mathrm{I}$ votes were cast at the election it is obvious that less than half of those who voted at the election voted in favor of the proposal. It was therefore immaterial that there may have been further eligibles who did not vote at all. I know of no Wyoming case in which the problem of determining the size of the electorate was squarely presented, that is, one in which more than half of those voting at a general election voted in favor of a proposed amendment, but one in which the contention was made that the amendment was supported by less than half of those eligible to vote.

II This reference is to the period prior to the decision in In re Todd, 208 Ind. r68, $x_{93}$ N.E. 865 (I935), which has completely changed the Indiana doctrine and practice to conform to that prevailing throughout the United States.

${ }^{12} 69$ Ind. 505 ( 1880 ). This was by way of dictum. Like the Wyoming case, actually the affirmative votes were less than half of the total vote cast at the election.

${ }^{23}$ In re Denny, I56 Ind. 104, 59 N.E. 359 (Ig0r); In re Boswell, 179 Ind. 292, 100 N.E. 833 (xgr3).

14 Green v. State Board of Canvassers, 5 Idaho I30, 47 Pac. 259 (I896). 
persons voting at a particular election. ${ }^{x 5}$ As above pointed out, since the case of $I n$ re Todd, ${ }^{16}$ Indiana has followed the same construction and practice as Idaho. ${ }^{17}$

The problem of selecting the states to be considered in this essay involves a degree of discrimination. Arkansas, Mlinois, Indiana, Minnesota, North Carolina, Oklahoma, Tennessee, Texas, and Wyoming have been classified as states in which, in order to obtain a constitutional amendment, a favorable majority of all those voting for any purpose at a general election must be obtained. ${ }^{x}$ Another source ${ }^{x}$ included Arkansas, Illinois, Minnesota, Mississippi, Oklahoma, Tennessee, and Wyoming, a list differing from that found in State Government by omitting Indiana, North Carolina, and Texas, and including Mississippi. Professor Dodd, ${ }^{20}$ writing in IgIo, listed the states involved as Alabama, Arkansas, Illinois, Indiana, Minnesota, Mississippi, Nebraska, Ohio, Oklahoma, Tennessee, and Wyoming. ${ }^{2 x}$ Several changes have occurred since Professor Dodd

${ }_{15}$ Compare Stebbins v. Judge of Superior Court of Grand Rapids, xo8 Mich. 693, 66 N.W. 594 (1896); The State ex rel. Allen v. Mayor of St. Louis, 73 Mo. 435 (188I); and People v. Town of Berkeley, I02 Cal. 298, 36 Pac. 59I (I894). In each of these cases a majority of all votes cast at a general municipal election was necessary in order to obtain popular approval on official actions of a non-constitutional nature, that is, approval of a bond issue in the case first cited. In the first two cases the statutes involved permitted submittal at either a general or a special election, but in those cases the general elections were involved. In the third of the above cases the statute required that the submittal be at a general election. When the chicaneries of municipal politics are considered, one can understand why a rule different from that used in constitutional amendment may be necessary.

${ }^{56} 208$ Ind. 168 , I93 N.E. 865 (I935); see also note 9 supra.

${ }^{17}$ It was aptly pointed out that under the previous Indiana rule, since special elections are permitted in that state, it would be possible for an amendment to be adopted at a special election with an affirmative vote of less than the vote cast against it at a previous general election. In State v. Swift, 69 Ind. 505 ( 1880 ), a case which established the old Indiana rule, such a phenomenon in fact took place. An amendment to liberalize the suffrage requirements was declared defeated because it failed to obtain an affirmative vote of more than half the total vote cast at the general election at which it was submitted, although the affirmative vote exceeded the negative. Later the same amendment was submitted to the voters at a special election and was ratified, although the affirmative vote was less than the negative'vote cast at the prior general election. See Chattin, op. cit. supra note 9 .

${ }^{18} 7$ State Government 264 (1934). The inclusion of Indiana is explained by the fact that the list was compiled before the decision in In re Todd, 208 Ind. I68, I93 N.E. 865 (I935).

19 Chipp, Fundamental Attitude of the American People Regarding the Amending Process (1938), an unpublished thesis classified in the Library of Congress as Number J. K. 242I.

${ }^{20}$ Dodd, op. cit. supra note ro, at 134, I87.

${ }^{2 x}$ He also noted that Oregon had previously employed that system but had changed its method of amendment in I906. My own investigation does not reveal that Oregon ever required that a proposed amendment be ratified by a majority of all votes cast for any purpose at a general election. Oregon statistics of votes on proposed constitutional amendments date as far back as I902, but they do not state the total vote at the elections. However, they indicate that an amendment was ratified if there were more affirmative votes than negative votes. 
wrote. ${ }^{22}$ Therefore, a brief survey of the constitutional provisions, practices, and doctrines of the designated states may be of some avail.

The North Carolina Constitution provides that for adoption an amendment must be approved "by a majority of the votes cast." A search for a judicial construction of this language has not been rewarded, but an amendment is regarded by an administrative officer in North Carolina as ratified, if the affirmative votes upon the amendment exceed the negative. ${ }^{23}$ Thus, North Carolina is not a state that will be included in this survey. Texas would require no notice but for the fact that the list in State Government includes it with such states as Tlinois. If any doubt is apparent from the wording of the Texas Constitution it has been dispelled by the Texas Supreme Court. ${ }^{24}$

\section{AMENDMENT EXPERIENCE OF SPECIFIC STATES}

Alabama-Under the Alabama Constitution of 1875 , a proposed amendment was not ratified unless it was approved by a majority of all those voting for any purpose at the general election at which the amendment was submitted. ${ }^{25}$ An amendment was adopted in I9oI, and it appears to have been intended to remedy this defect, but it was not absolutely free from doubt. ${ }^{26}$ As late as I910, Professor Dodd listed Alabama as a state that still required, to adopt an amendment, a majority of all the votes cast for any purpose at a general election. ${ }^{27}$ And it is inferable from

${ }^{22}$ See note 6 supra.

${ }^{23}$ A personal letter received from Mr. T. Eure, Secretary of State of North Carolina, in part follows: ". . . . after an amendment has been proposed by the legislature of North Carolina and it is submitted to the people for ratification, it is sufficient that more votes be cast for the amendment than against it in order to ratify same."

${ }_{24}$ Itasca School District v. McElroy, I03 Tex. 64, I23 S.W. Ix7 (Ig09). The constitution provides that an amendment shall be effective "if it shall appear from said return that a majority of the votes cast have been cast in favor" of it. The supreme court squarely defined the problem as the determination of what is meant by "votes cast" and decided that that term referred to the votes cast for or against a proposed amendment, without reference to the total vote cast at the election.

25 The Constitution of 1875 specifically required that if "a majority of all the qualified electors of the state, who voted at said election, voted in favor of the proposed amendments, said amendments shall be valid. . . ." Cf. May v. Mayor and Aldermen of Birmingham, I 23 Ala. 306,26 So. $537(x 899)$, in which it was held that the legislature could legally provide that any one who failed to scratch the proposed amendment from his ballot would be considered as having voted in favor of it.

${ }^{26}$ Section 284 was amended to provide that proposed amendments should be ratified if voted upon affirmatively, by "a majority of the qualified voters who voted at said election upon the proposed amendments." Section 285 , however, after specifying details as to how an amendment should appear upon the ballot, provided that "no amendment shall be adopted unless it receives the affirmative vote of a majority of all the qualified voters who vote at such election."

27 Dodd, op. cit. supra note ro at 187. 
his book that there existed an administrative practice to this effect. If such a practice existed it was abandoned prior to I9I2. ${ }^{28}$ This doubtful situation was settled in $I 9 I \eta$ in Harris $v$. Walker, ${ }^{29}$ which interpreted the amendment of Igor, and held that an amendment which had failed to receive a majority of all the votes cast at a general election had been adopted. ${ }^{30}$

A thorough search at the capitol of Alabama failed to reveal any statistics of the votes cast on proposed amendments in Alabama prior to the amendment of IgOI. It appears that the situation regarding constitutional amendments must have become deplorable, because in 1898 the Alabama legislature submitted an amendment with a provision that the ballot should have printed upon it the words "For Birmingham Amendment" without any negative statement of the proposition; and that any voter who did not erase or strike out these words with pen or pencil should be counted as having voted for the amendment. By grace of this device the amendment received a majority of all votes cast at the general election. This method of voting was sustained as valid despite the wording of the Alabama Constitution before it was amended in Igor..$^{3 \mathrm{~K}}$

Professor Dodd enumerates three proposed amendments that were sub-

${ }^{28}$ Statistics of the voting upon proposed constitutional amendments in Alabama have not been officially published, but the statistics since 19 I 2 are available at the capitol of the state. These show only the votes for and against proposed amendments. The total vote cast at the various elections at which the amendments were submitted has not been recorded. It is evident, therefore, that a preponderance of affirmative votes was considered sufficient for ratification.

${ }^{29}$ x99 Ala. 5I, 74 So. 40 (I9I7).

${ }^{30}$ Two arguments were advanced against the amendment. I) Section 284 referring to proposed amendments, required that each proposed amendment receive a majority of the largest vote cast upon any amendment, whenever two or more amendments are submitted at the same election. This was held to be untenable. 2) Reliance was.placed upon the provisions of Section 285 , but the court held that this section should be construed in pari materia with the preceding section, and that the word "election" meant the vote upon the particular proposal.

$3 x$ May v. Mayor and Alderman of Birmingham, I23 Ala. 306, 26 So. 537 (189g). The statute provided that after the names of candidates for state offices, and before the names of the candidates for county offices, should appear the statement "For the Birmingham Amendment." It was argued in this case that a majority of the votes obtained at an election by the use of such a ballot did not constitute a majority of all votes cast at the election "within the spirit and meaning of the constitution" because it did not establish that a majority of the voters actually favored the amendment. The court had two answers. I) All voters are presumed to know what is on their ballots, and thus, if they were opposed to the amendment, they would have scratched the statement. 2) Literally the constitution was complied with, and a majority of the votes were cast in favor of the amendment irrespective of what the voters may have intended. It was also argued that this device in effect compelled a general election voter to vote one way or the other on an amendment and that compulsory voting was not authorized by the constitution. The court answered that this ballot device did not compel a voter to vote one way or the other any more than was true under the constitution when an ordinary ballot was used. It merely changes the effect of a failure to vote. 
mitted to the Alabama voters in the general election of $1908 . .^{32}$ One, providing for a system of good roads, received 45,794 affirmative votes as against 25,806 negative votes, but it failed of adoption because it did not receive a majority of 103,399 , the total vote cast at the general election. Information prior to I9I 2 is unavailable, but thereafter amendments were regarded by the administrative authorities as adopted if they received a majority of the votes cast thereon..$^{33}$

During I924 seven amendments were proposed in Alabama and all were ratified. ${ }^{34}$ In only one instance, however, was the affirmative vote in excess of 50 per cent of the total vote cast in the general election. This was subsequent to the decision in Harris $v$. Walker, ${ }^{35}$ and the deficiency in the favorable vote on the other amendments was not material, The affirmative votes received by the other six proposals varied from $4 \mathrm{I}$ to 46 per cent of the total vote cast at this I924 election. These percentage figures assume an increased significance when it is remembered that suffrage is very much restricted in the southern states. It would appear that a larger percentage of the electorate in these states would be likely to take an interest in constitutional amendment than would be the case in many other states.

Arkansas-The clear wording of the Arkansas Constitution ${ }^{36}$ has caused that state to be classified as one in which a majority of all those voting at a general election for any purpose is required. ${ }^{37}$ Such was the uniform holding of the early cases. ${ }^{38}$

Between 1899 and I908 seven proposed amendments were submitted

${ }^{32}$ Dodd, op. cit. supra note ro, at 295.

33 This latter statement is based upon the fact that in the files in the Secretary of State's office containing the election returns, amendments which received more affirmative than negative votes carry the notation "adopted." At the same time no statement as to the total number of votes cast at the general elections, at which the amendments were submitted, accompanied the data as to the votes upon the amendments. Evidently, after IgI 2 the administrative officers of Alabama construed the amendment of rgor as having removed the necessity that an amendment obtain a majority of all votes cast at a general election in order to be adopted. The construction was upheld in Harris v. Walker, I99 Ala. 5I, 74 So. 40 (I9I7).

34 See the table in 40 Pol. Sci. Q. Supp. 84 ( rg25$^{25}$ ) (complete information on 1924 election). There were amendments voted upon between $x_{908}$ and $\mathrm{r}_{924}$, and others after 1924, but information as to the total vote cast at the various general elections at which they were submitted is lacking.

35 I99 Ala. 5I, 74 So. 40 (I9I7).

${ }^{36}$ Ark. Const. art. $19, \S 22$, provides that "if a majority of the electors voting at such election adopt such amendments the same shall become a part of this Constitution."

37 See page $I_{45}$ and notes $I_{9}$ and 22 supra.

${ }^{38}$ Rice v. Palmer, 78 Ark. 432, 96 S.W. 396 (rgo6); St. Louis Southwestern Railway Co. v. Kavanaugh, 78 Ark. 468, 96 S.W. 409 (Ig06); Knight v. Shelton, I34 Fed. 423 (Ig05). 
to the voters in Arkansas. ${ }^{39}$ Two were successful because they received a majority of the total vote cast at the general election. One amendment, providing for a poll tax, received 92,969 out of $I_{5}$ I, 848 votes or 62 per cent of the total, as against 47,368 negative votes, or 3 I per cent; the other, which made payment of the poll tax a requirement of the right to vote, received 88,368 out of a total of $x 6_{3}, 674$ votes, or 54 per cent of the total, as against 46,835 votes ( 28 per cent). The other five proposed during this period failed. Two of them received more negative than affirmative votes. One of the remaining three affected the pay of members of the General Assembly. Although receiving 45,598 votes ( 38 per cent of the total cast at the election) as against 43,982 votes ( 36 per cent), it failed because it lacked a majority of the II9,74I votes cast at the general election. Another which failed was an amendment to forbid the loan of credit by cities, counties, or the state. It received 45, I 98 affirmative votes ( $3 \circ$ per cent), and $44,37^{8}$ negative votes ( 29 per cent) out of a total of $\mathrm{I} 49,780$ votes cast at the general election.

In Igro an adopted amendment provided that amendments might be submitted to the voters by initiative petitions. This amendment also provided that "any measure referred to the people shall take effect and become a law when it is approved by a majority of the votes cast thereon and not otherwise."

Further statistics are available on the State of Arkansas for the years I9I $7-I 9 I 8,4^{40}$ IgI9-I92I, ${ }^{4 \mathrm{I}}$ and $1924 .{ }^{42}$ During these periods ten proposals were presented to the Arkansas voters. Four were adopted, and three were defeated by a majority of negative votes on the proposals themselves. Three, all voted upon in I924, were defeated although they received more affirmative than negative votes. Thus, an amendment fixing a debt limitation upon municipal corporations was not adopted, although it received 57,854 affirmative votes as against 35,449 negative votes; a proposal to increase the size of the supreme court lost even though it received $5^{2},{ }^{5}{ }^{I}$ affirmative votes as against 40,955 negative votes; and a proposed amendment to give municipalities a larger measure of local autonomy was defeated with an affrmative vote of 56,9 Io as against 34, I 74 negative votes. 43

39 Dodd, op. cit. supra note ro at 295.

${ }^{\circ}$ See the table in Kettleborough, Amendments to State Constitution, I3 Am. Pol. Sci. Rev. 429, 439 (rorg).

${ }^{4 x}$ See the table in Dodd, Amendments to State Constitutions rgrg-2I, I6 Am. Pol. Sci. Rev. 245, 249 (I922).

42 Table in 40 Pol. Sci. Q. Supp. 84,85 (I925).

43 The table from which these figures are taken does not give the total vote at the election. 
However, in Brickhouse v. Hill 44 it was held that the initiative amendment had changed the system of ratification as far as amendments proposed by the initiative were concerned, and that as to such proposals, a majority voting upon that issue sufficed. 45 The next year Combs v. Gray ${ }^{46}$ applied the ruling in Brickhouse v. Hill to an amendment proposed by the legislature. It held that the initiative amendment had changed the method of ratification for all amendments, however proposed. 47

Arkansas never resorted to an unusual ballot provision, such as was successfully invoked in Alabama, to obtain ratification of proposed amendments. Constitutional proposals were submitted to the voters upon the right-hand side of the official election ballot. However, prior to the decision in Combs v. Gray a curious practice arose in Arkansas, and it amounted to an amendment of the constitution even though the amendment had not been legally adopted..$^{8}$

Illinois-Seventeen amendments to the Ilinois Constitution of 1870 and two proposals to call a constitutional convention have been submitted to the Tllinois voters, as disclosed by Table I. ${ }^{49}$

The five amendments that were submitted before I89r received more than 50 per cent of the total vote cast at the general election and

44 $x 67$ Ark. 513 3, 268 S.W. 865 (1925).

45 The same question had been previously presented in Hildreth v. Taylor, II 7 Ark. 465 , I75 S.W. 40 (I9I5), and a contrary result was reached. It was held that the initiative amend ment merely added a method of proposing amendments and did not change the method of ratification. Hildreth v. Taylor was overruled by Brickhouse v. Hill.

${ }^{6}$ x 70 Ark. 956, 28 r S.W. 9 I8 (r926).

17 Viewed objectively this Arkansas decision is hardly tenable. Probably, the legislature, which proposed the initiative amendment, intended only to add an additional method by which amendments might be proposed. It is hard to believe that it intended to change the method of ratification of legislatively proposed amendments. But the decision was fortunate. There seems to be more justification in requiring a majority of all those voting at a general election in the case of an amendment proposed by the initiative than in the case of one proposed by the state legislature. In the former situation the possibility of minority action is clear. In the latter, before an amendment is submitted, a resolution has passed a representative body, in many states by a two-thirds vote.

${ }^{8}$ Thomas, Amending a State Constitution by Custom, 23 Am. Pol. Sci. Rev. 920 (I928). An amendment to permit the governor to fill vacancies "in any state, district, county, or township office" by appointment was submitted in 1893 . It received a majority of those who voted on that issue, but not a majority of those voting at the election. In Ig06 this amendment was held invalid in Rice v. Palmer, 78 Ark. 432, 96 S.W. 396, because it had not received a majority of all who voted at the general election. Nonetheless the practice of filling vacancies, including in some instances vacancies in the general assembly, by gubernatorial appointment, continued. This practice had changed the constitution despite the decision of the court.

${ }^{49}$ Sears, Voting on Constitutional Conventions and Amendments, 2 Univ. Chi. I. Rev. 6 I2 (1935); Sears, Constitutional Revision in Illinois, 33 III. I. Rev. 2 (1938); Sears, The Illinois Constitution and the Banking Amendment, 6 Univ. Chi. I. Rev. 234 (I939); Sears, loc. cit. supra note 5; Powell, A Plan for Facilitating Constitutional Amendment in Illinois, 30 Ill. L. Rev. 59 (I935). 
TABLE 1

\begin{tabular}{|c|c|c|c|c|c|c|}
\hline $\begin{array}{c}\text { Year and } \\
\text { Amendment }\end{array}$ & $\begin{array}{l}\text { Total Vote } \\
\text { Cast at } \\
\text { Election }\end{array}$ & $\begin{array}{l}\text { Necessary } \\
\text { Majority }\end{array}$ & For & Against & Not Voting & Result \\
\hline $\begin{array}{l}\text { I878: Drainage } \\
\text { and Ditching }\end{array}$ & 448,796 & 224,399 & $\begin{array}{c}295,960 \\
(65.9 \%)\end{array}$ & $\begin{array}{r}60,081 \\
(13.4 \%)\end{array}$ & $\begin{array}{c}92,755 \\
(20.7 \%)\end{array}$ & Adopted \\
\hline $\begin{array}{l}\text { I880: County } \\
\text { Officers }\end{array}$ & 622,306 & $3 I I, x 54$ & $\left(\begin{array}{l}321,552 \\
(51.7 \%)\end{array}\right.$ & $\begin{array}{c}103,966 \\
(16.7 \%)\end{array}$ & $\begin{array}{r}196,788 \\
(3 \pm .6 \%)\end{array}$ & Adopted \\
\hline $\begin{array}{c}\text { I884: Veto of } \\
\text { Appropria- } \\
\text { tion Items }\end{array}$ & 673,096 & 336,549 & $\begin{array}{l}427,821 \\
(63.6 \%)\end{array}$ & $\begin{array}{l}60,244 \\
(8.9 \%)\end{array}$ & $\begin{array}{l}x 85,03 x \\
(27.5 \%)\end{array}$ & Adopted \\
\hline $\begin{array}{l}\text { I886: Anti- } \\
\text { Contract } \\
\text { Convict } \\
\text { Labor }\end{array}$ & 574,080 & 287,041 & $\begin{array}{c}306,565 \\
(53.4 \%)\end{array}$ & $\begin{array}{l}169,327 \\
(29.5 \%)\end{array}$ & $\begin{array}{r}98, x 88 \\
(17.1 \%)\end{array}$ & Adopted \\
\hline $\begin{array}{l}\text { r8go: World's } \\
\text { Fair Bonds }\end{array}$ & 677,817 & 338,909 & $\begin{array}{c}500,299 \\
(73.8 \%)\end{array}$ & $\begin{array}{l}55,073 \\
(8 . x \%)\end{array}$ & $\begin{array}{l}122,445 \\
(18 . x \%)\end{array}$ & Adopted \\
\hline $\begin{array}{l}\text { I892: Gate- } \\
\text { way Amend- } \\
\text { ment* }\end{array}$ & $871,5 \circ 8$ & 435,755 & $\begin{array}{l}84,645 \\
(9.7 \%)\end{array}$ & $\begin{array}{r}93,420 \\
(10.7 \%)\end{array}$ & $\begin{array}{r}693,443 \\
(79.6 \%)\end{array}$ & Defeated \\
\hline I894: Labor & 873,426 & $43^{6}, 714$ & $\begin{array}{l}\text { I55,393 } \\
(\mathbf{1} 7.8 \%)\end{array}$ & $\begin{array}{c}59,558 \\
(6.8 \%)\end{array}$ & $\begin{array}{r}658,475 \\
(75 \cdot 4 \%)\end{array}$ & Not adopted $\S$ \\
\hline $\begin{array}{l}\text { I896: Gate- } \\
\text { way Amend- } \\
\text { ment }\end{array}$ & $I, 090,869$ & 545,435 & $\begin{array}{l}\mathrm{x}_{3}, 057 \\
(\mathrm{r} 4.9 \%)\end{array}$ & $\begin{array}{c}66,519 \\
(6.1 \%)\end{array}$ & $\begin{array}{l}86 \mathrm{r}, 293 \\
(78.9 \%)\end{array}$ & Not adopted \\
\hline $\begin{array}{l}\text { rgo4: Chicago } \\
\text { Chartert }\end{array}$ & $I, \circ 89,45^{8}$ & $\begin{array}{c}544,730 \\
1\end{array}$ & $\begin{array}{c}678,393 \\
(62.3 \%)\end{array}$ & $\begin{array}{l}90,038 \\
(8.2 \%)\end{array}$ & $\begin{array}{l}321,027 \\
(29.5 \%)\end{array}$ & Adopted \\
\hline $\begin{array}{l}\text { I908: Deep } \\
\text { Waterway } \\
\text { Bonds }\end{array}$ & г, 169,330 & 584,666 & $\begin{array}{c}692,522 \\
(59.2 \%)\end{array}$ & $\begin{array}{r}x 95,177 \\
(17.7 \%)\end{array}$ & $\begin{array}{c}28 I, 63 I \\
(24.1 \%) \\
(\text { sic })\end{array}$ & Adopted \\
\hline $\begin{array}{l}\text { I9r6: Revenue } \\
\text { Amendment }\end{array}$ & $x, 343,38 \mathrm{I}$ & 671,691 & $\begin{array}{c}656,298 \\
(48.9 \%)\end{array}$ & $\begin{array}{l}295,782 \\
(22.0 \%)\end{array}$ & $\begin{array}{c}391,301 \\
(29.1 \%)\end{array}$ & Not adopted \\
\hline $\begin{array}{l}\text { r9r8: To Call } \\
\text { a Constitu- } \\
\text { tional Con- } \\
\text { Convention }\end{array}$ & 975,545 & 487,773 & $\begin{array}{l}562, \text { or } 2 \\
(57.6 \%)\end{array}$ & $\begin{array}{l}I 62,206 \\
(16.6 \%)\end{array}$ & $\begin{array}{c}25 \mathrm{x}, 327 \\
(25.8 \%)\end{array}$ & Adopted \\
\hline $\begin{array}{l}\text { I924: Gate- } \\
\text { way Amend- } \\
\text { ment }\end{array}$ & $2,579,860$ & $I, 289,93 I$ & $\begin{array}{l}704,665 \\
(27.3 \%)\end{array}$ & $\begin{array}{l}397,835 \\
(15.4 \%)\end{array}$ & $\begin{array}{c}I, 477,360 \\
(57.3 \%)\end{array}$ & Not adopted \\
\hline $\begin{array}{l}\text { I926: Revenue } \\
\text { Amendment }\end{array}$ & I,9I2,706 & 956,354 & $\begin{array}{r}651,768 \\
(34.1 \%)\end{array}$ & $\begin{array}{c}476,455 \\
(24.9 \%)\end{array}$ & $\begin{array}{l}784,483 \\
(4 x .0 \%)\end{array}$ & Not adopted \\
\hline
\end{tabular}

* Notice the great difference in the record after the Ballot Act of $r 89 \mathrm{r}$ took away from the political parties the function of printing their own ballots.

† In I8g9 the separate or "little" ballot was adopted for constitutional proposals.

\$ The term "not adopted," as used in this and subsequent tables, is used to describe the results of elections in which the votes for the amendments exceed those against, but the amendments fail of adoption because they do not obtain a majority of all votes cast at the election. The term "defeated" is used in instances in which the negative votes exceed the affirmative. I am indebted to Professor Dodd for this distinction. 
TABLE 1-Continued

\begin{tabular}{|c|c|c|c|c|c|c|}
\hline $\begin{array}{l}\text { Year and } \\
\text { Amendment }\end{array}$ & $\begin{array}{l}\text { Total Vote } \\
\text { Cast at } \\
\text { Election }\end{array}$ & $\begin{array}{l}\text { Necessary } \\
\text { Majority }\end{array}$ & For & Against & Not Voting & Result \\
\hline $\begin{array}{l}\text { 1930: Revenue } \\
\text { Amend- } \\
\text { mentf }\end{array}$ & $2,332,696$ & $I, I 66,349$ & $\begin{array}{c}37 \mathrm{I}, 8 \mathrm{Ir} \\
(\times 5.9 \%)\end{array}$ & $\begin{array}{r}513,86 \mathrm{r} \\
(22.0 \%)\end{array}$ & $\begin{array}{c}I, 447,023 \\
(62.1 \%)\end{array}$ & Defeated \\
\hline $\begin{array}{l}\text { I932: Gate- } \\
\text { way Amend- } \\
\text { ment }\end{array}$ & $3,465,926$ & $I, 73^{2}, 964$ & $\begin{array}{r}\mathrm{I}, 080,54 \mathrm{I} \\
(3 \mathrm{I} .2 \%)\end{array}$ & $\begin{array}{l}275,329 \\
(7.9 \%)\end{array}$ & $\begin{array}{r}2, x 10,056 \\
(60.9 \%)\end{array}$ & Not adopted \\
\hline $\begin{array}{l}\text { I934: 'To Call } \\
\text { a Constitu- } \\
\text { tional Con- } \\
\text { vention }\end{array}$ & $2,935,192$ & $I, 467,597$ & $\begin{array}{c}69 \mathrm{I}, \mathrm{O} 2 \mathrm{I} \\
(23.5 \%)\end{array}$ & $\begin{array}{c}585,879 \\
(20 \%)\end{array}$ & $\begin{array}{r}\text { I }, 658,292 \\
(56.5 \%)\end{array}$ & Not adopted \\
\hline r938: Banking & $3,274,8 \times 4$ & $\mathrm{I}, 637,408$ & $\begin{array}{l}922,237 \\
(28.1 \%)\end{array}$ & $\begin{array}{c}35^{2}, 428 \\
\text { (10.8\%) }\end{array}$ & $\begin{array}{c}2,000,149 \\
(61.9 \%)\end{array}$ & Not adopted \\
\hline $\begin{array}{l}\text { 1942: Sales } \\
\text { Tax on Food } \\
\text { May Be Re- } \\
\text { moved }\end{array}$ & $3,049,312$ & $I, 524,657$ & $\begin{array}{r}979,892 \\
(32.2 \%)\end{array}$ & $\begin{array}{c}346,232 \\
(\mathrm{II} .3 \%)\end{array}$ & $\begin{array}{r}\mathrm{r}, 723, \mathrm{I} 88 \\
(56.5 \%)\end{array}$ & Not adopted \\
\hline
\end{tabular}

In I929, the Emmerson law became effective.

thus were adopted. Between I89x and I943 only two of twelve proposed amendments have been adopted by the voters, although all but two amendments received a majority of the vote cast thereon. As a result, eight times out of twelve the will of a majority of those sufficiently interested in the proposals to vote upon them has been thwarted.

Prior to $189 \mathrm{x}$ ballots in Tllinois could be printed by political parties or by any individual who chose to do so. In those days a party could and did print upon its ticket a statement merely approving a proposed constitutional amendment. All such ballots which were left unchanged in this respect by the voters were counted according to the position of the party. Such was the system of voting familiar to the drafters of the Illinois Constitution of 1870 . Under this system the adoption of constitutional amendments was not difficult, for, out of five proposed amendments, five were adopted. After the Australian Ballot Act was made a law and until I899, constitutional proposals were placed beneath the names of the candidates on the blanket ballot. This was an obscure place as the voting in $1892, \mathrm{r} 894$, and $\mathrm{r} 896$ clearly indicated. The affirmative votes were a pitiful percentage of those who voted in the general elections.

In r899 Mlinois started printing proposed amendments upon a ballot separate and distinct from the ballot with the names of the candidates for office. This separate or "little" ballot was supposed to awaken interest 
in proposed amendments, and at first it appeared to have that result because the next two to be proposed were adopted. Then the separate ballot apparently became ineffective, and in I929 the separate ballot law was repealed. Thereafter the legislature provided that amendments should appear upon the ballot that carried the names of candidates for office in a separate column on the left side of that ballot. It was thought that such a ballot would further stimulate voting upon constitutional amendments, but, to date, it has apparently failed to attract as much interest as the separate ballot did after $\mathrm{x} 899$ and prior to $1929 . .^{50}$

The first of the two amendments to be adopted after 1899 , by use of the separate or "little" ballot, was one granting Chicago a limited measure of home rule. This was adopted as the result of intense political activity ${ }^{5 x}$ of a type seldom duplicated. The other was a proposal to authorize deep waterway bonds and was a matter of no basic governmental importance. A constitutional convention was authorized by a vote in November, I9I8. The vote was taken on an opportune occasion that will not be duplicated very often.

There has been, and still is, considerable agitation for constitutional reform in Illinois, including the method of constitutional amendment. But the very vice in the method of amendment makes it difficult to adopt a new method calculated to facilitate amendment. Two types of ballot have been proposed to facilitate the amending process prior to the adoption of a formal change in the process, and in particular to render feasible the adoption of a true "gateway amendment," that is, an amendment to amend the article permitting an amendment of the constitution. This will permit an amendment to be adopted if there is a preponderance of affirmative over negative votes on the particular amendment. The first of these two types of ballots is embodied in what is known as the "party circle bills." It would simulate the type of ballot used prior to the adoption of the Australian ballot system in Illinois, by permitting political parties to print in their party columns a statement endorsing or opposing proposed amendments, and by counting all party circle votes according to the party stand unless otherwise indicated by the voter. This type of ballot was successfully used in both Nebraska and Ohio prior to the time that the amending process was changed in those states. The other type of proposed ballot is more drastic. The use of it in Illinois has been advocated by the Cook County Judicial Advisory Council. Under it the candidates'

${ }^{50}$ For the text of the present Illinois ballot law see Ill. Rev. Stat. (I94I) c. $46, \S 304 a$.

${ }^{51}$ Gardner, The Working of the State-Wide Referendum in Illinois, 5 Am. Pol. Sci. Rev. 394 (IgII). 
ballot in a general election would carry a statement that the ballot would be cast for the proposed amendment, that is, the "gateway amendment" to facilitate the amending process. Unless the voter should indicate a contrary desire by scratching out this statement, the ballot would be counted for the proposal. This is the type of ballot that was successfully used in Alabama and is substantially the same as the ballot that was used in adopting the Mllinois Constitution of 1870 and the optional provisions thereof. ${ }^{5^{2}}$ This latter usage suggested to the Council that it should be used once again to get Illinois out of its constitutional bog.

The text of the true "gateway amendment" suggested by the Council to Article XIV of the Mllinois Constitution, the section dealing with the manner of amendment, provides in part:

"Such amendments shall be submitted to the electors for adoption or rejection at the next general election to be held throughout the State, or at a special election to be called for the purpose, as the General Assembly may direct, and shall be published in full for at least three months preceding the election. If a majority of the electors voting thereon shall affirmatively cast their votes by mark or writing, as may be prescribed by law, for any proposed amendment, it shall become part of this Constitution. But the General Assembly shall have no power to propose amendments to more than three articles of this Constitution at the same session nor to the same article oftener than once in four years."

The word "affirmatively" has been italicized because that is the crucial word, according to the Council, that will presumably prevent the use of this drastic ballot or the party circle ballot, after the "gateway amendment" is adopted. It is doubtful whether the word "affirmatively" will mean as much. However, the text could be changed so that the specified object could be accomplished. In the meantime, it is clear that for practical purposes Illinois has a constitution that cannot be amended under the present system of voting.

52 Section Io of the Schedule of the Illinois Constitution of 1870 provides:

At the said election the ballots shall be in the following form:

NEW CONSTITUTION TICKET

For all the propositions on this ticket which are not cancelled with ink or pencil; and against all propositions which are so cancelled.

For the New Constitution.

For the sections relating to railroads in the article entitled "Corporations."

For the article entitled "Counties."

For the article entitled "Warehouses",

For a three-fifths vote to remove County Seats.

For the section relating to the Illinois Central Railroad.

For the section relating to Minority Representation.

For the section relating to Municipal Subscriptions to Railroads or Private Corporations.

For the section relating to the Canal.

Each of said tickets shall be counted as a vote cast for each proposition thereon not cancelled with ink or pencil, and against each proposition so cancelled, and returns thereof shall be made accordingly by the judges of election. 
Indiana-It has been pointed out ${ }^{53}$ that prior to I935 a majority of all votes cast was necessary to effectuate constitutional amendment in Indiana. The Indiana requirement was not as prohibitive as those of other states being considered because the Indiana legislature could designate that amendments be submitted to the voters at special elections. ${ }^{54}$ The method of amendment in Indiana was changed in I935 by a judicial decision, and now an amendment is ratified if more votes are cast for it than against it. Table 2 is a record of all amendments proposed to the voters of Indiana since 1851.55

From Table 2 it is apparent that the voters have voted 46 times since I85I upon constitutional proposals. The figures may be further analyzed as shown in Table 3 .

Although there were forty-six distinct votes, because of repetitions, there have been only thirty-three different propositions voted upon. The amendment to change the qualifications for permission to practice law was voted upon five times, ${ }^{56}$ and the amendment to authorize an income tax was voted upon three times. ${ }^{57}$ In addition to these, seven amendments which failed of adoption in the general election of 1880 because they did not receive a majority of all votes cast at the general election, although they all received a majority of the votes cast thereon, were again submitted at the special election of $\mathrm{I} 88 \mathrm{I}$ and adopted. It is interesting to note that in every instance the affirmative vote in I88I, which was sufficient for adoption, was less than the negative vote in 1880 .

The availability of the special election in Indiana and the decision of its supreme court in In re Todd rendered it unnecessary for Indiana to resort to any particular type of ballot in order to obtain the ratification of necessary constitutional amendments. By a general law, Indiana required that proposed amendments be printed on the same general election ballot as that upon which the names of the candidates for office are printed. In practice, however, the legislative resolutions submitting amendments to

53 See page $I_{43}$ and notes $9-\mathrm{r}_{4}$ supra.

54 In Oklahoma, amendments may be submitted at the special elections, but only in case two-thirds of each house of the legislature so designate. No such limitation obtains in Indiana.

35 The information contained in this table was furnished me by Miss Emma Phillipp, a graduate student at the University of Indiana. She obtained it from the Indiana Historical Commission; Kettleborough, Constitution Making in Indiana (IgI6); and Sikes, Indiana State and Local Government (r940). The Indiana Year Book, r9I7 at 847 gives some further but inconclusive data on votes prior to $185 \mathrm{r}$.

${ }^{56}$ In I900, I906, I910, 1921, and 1932.

57 Defeated in I92 $\mathrm{I}$, and declared not adopted as a result of the elections in 1926 and $\mathrm{x} 932$. It is now probably effective as of $x 926$. 
TABLE 2

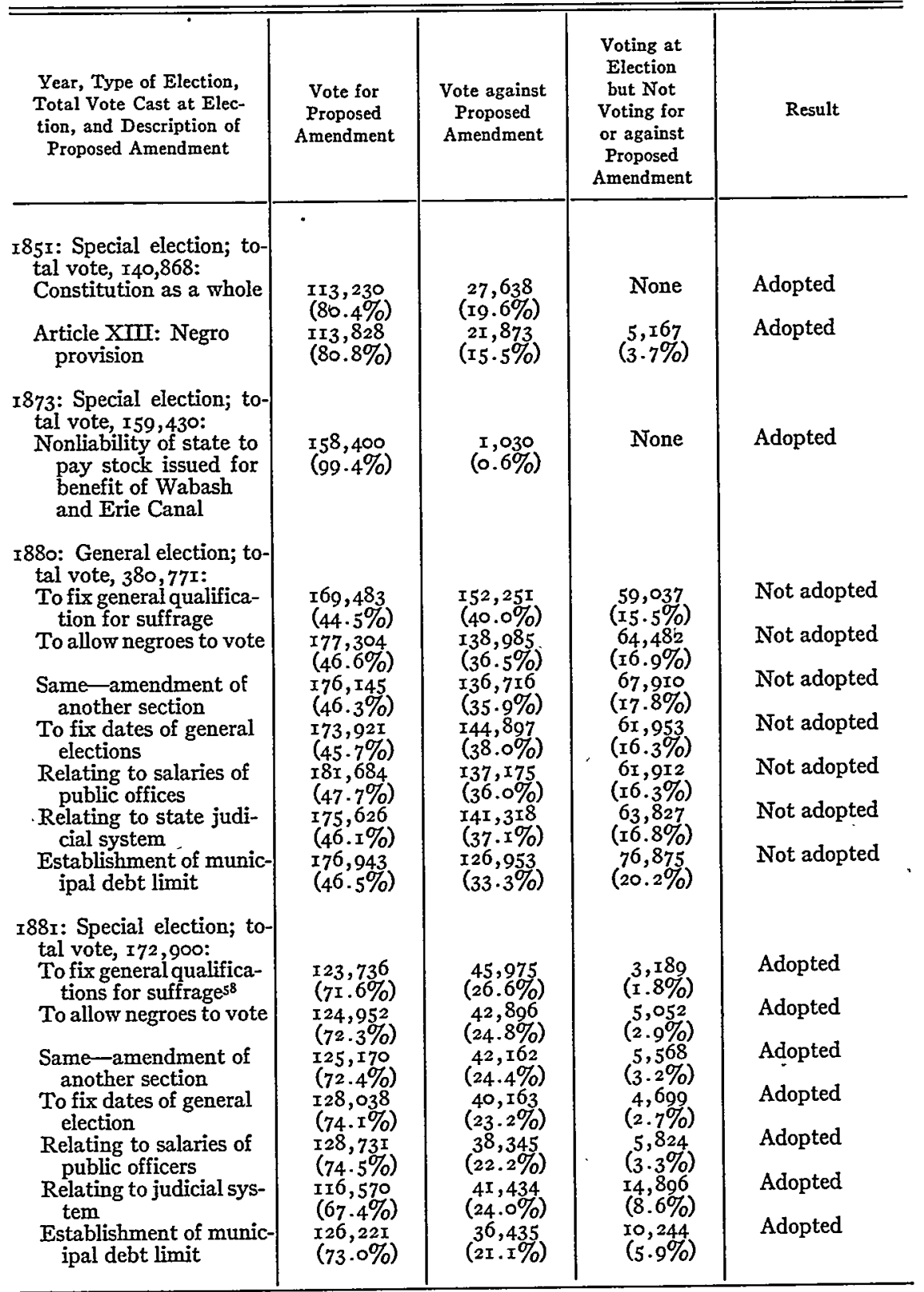

${ }^{88}$ All these amendments, submitted at the special election of $\mathrm{I88I}$, were the same as those submitted to the voters at the general election of 1880 . 
TABLE 2-Continued

\begin{tabular}{|c|c|c|c|c|}
\hline $\begin{array}{l}\text { Year, Type of Election, } \\
\text { Total Vote Cast at Elec- } \\
\text { tion, and Description of } \\
\text { Proposed Amendment }\end{array}$ & $\begin{array}{l}\text { Vote for } \\
\text { Proposed } \\
\text { Amendment }\end{array}$ & $\begin{array}{l}\text { Vote against } \\
\text { Proposed } \\
\text { Amendment }\end{array}$ & $\begin{array}{l}\text { Voting at } \\
\text { Election } \\
\text { but Not } \\
\text { Voting for } \\
\text { or against } \\
\text { Proposed } \\
\text { Amendment }\end{array}$ & Result \\
\hline $\begin{array}{l}\text { r9oo: General election; to- } \\
\text { tal vote, } 664,094: \\
\text { Legislature to prescribe } \\
\text { qualification to prac- } \\
\text { tice law }\end{array}$ & $\begin{array}{l}240,03 \mathrm{I} \\
(36.2 \%)\end{array}$ & $\begin{array}{l}\text { I } 44,072 \\
(21.7 \%)\end{array}$ & $\begin{array}{l}279,99 \mathrm{r} \\
(42.1 \%)\end{array}$ & Not adopted \\
\hline $\begin{array}{l}\text { Membership of Supreme } \\
\text { Court }\end{array}$ & $\begin{array}{l}314,710 \\
(47.4 \%)\end{array}$ & $\begin{array}{l}178,960 \\
(26.9 \%)\end{array}$ & $\begin{array}{l}170,424 \\
(25.7 \%)\end{array}$ & Not adopteds9 \\
\hline $\begin{array}{l}\text { 1906: General election; to- } \\
\text { tal vote, } 589,044: \\
\text { Legislature to prescribe } \\
\text { qualification to prac- } \\
\text { tice law } 60\end{array}$ & $\begin{array}{l}39,06 x \\
(6.6 \%)\end{array}$ & $\begin{array}{l}12,128 \\
(2.3 \%)\end{array}$ & $\begin{array}{l}537,855 \\
(91 . x \%)\end{array}$ & Not adopted \\
\hline $\begin{array}{l}\text { 1910: General election; to- } \\
\text { tal vote, } 627, \text {, I3: } \\
\text { Qualification to practice } \\
\text { law }\end{array}$ & $\begin{array}{l}60,357 \\
(9.6 \%)\end{array}$ & $\begin{array}{l}18,494 \\
(2.9 \%)\end{array}$ & $\begin{array}{l}548,242 \\
(87.5 \%)\end{array}$ & Not adopted \\
\hline $\begin{array}{l}\text { I9I4: General election:62 } \\
\text { Constitutional Conven- } \\
\text { tion }\end{array}$ & $235, \mathrm{I} 4 \mathrm{O}$ & $33^{8}, 947$ & & Defeated \\
\hline $\begin{array}{l}\text { 1921: Special election; to- } \\
\text { tal vote, } 218,698: \\
\text { Relating to qualification } \\
\text { of voters } \\
\text { Registration of voters }\end{array}$ & $\begin{array}{l}\text { I30,242 } \\
(59.6 \%) \\
90,269\end{array}$ & $\begin{array}{c}80,574 \\
(36.8 \%) \\
\text { r10,333 }\end{array}$ & $\begin{array}{l}7,882 \\
(3.6 \%) \\
18,096\end{array}$ & $\begin{array}{l}\text { Adopted } \\
\text { Defeated }\end{array}$ \\
\hline $\begin{array}{l}\text { Power in governor to } \\
\text { veto items in appro- } \\
\text { priation bills }\end{array}$ & $\begin{array}{c}(41.3 \%) \\
83,265 \\
(38.1 \%)\end{array}$ & $\begin{array}{l}(50.4 \%) \\
\text { Ior }, 790 \\
(46.5 \%)\end{array}$ & $\begin{array}{c}(8.3 \%) \\
33,643 \\
(15.4 \%)\end{array}$ & Defeated \\
\hline $\begin{array}{l}\text { Four-year terms for } \\
\text { county officers } \\
\text { Four-year terms for } \\
\text { prosecuting attorneys }\end{array}$ & $\begin{array}{c}82,389 \\
(37.8 \%) \\
76,587 \\
(35.0 \%)\end{array}$ & $\begin{array}{l}\text { II } 5, \text { I39 } \\
(52.5 \%) \\
\text { II6,683 } \\
(53.4 \%)\end{array}$ & $\begin{array}{c}21, \mathrm{r} 70 \\
(9.7 \%) \\
25,428 \\
(\mathrm{r1} .6 \%)\end{array}$ & $\begin{array}{l}\text { Defeated } \\
\text { Defeated }\end{array}$ \\
\hline
\end{tabular}

59 Prior to 1935 these amendments received a majority of the votes cast thereon; yet they were regarded as not adopted. What is their status, however, when considered in the light of the decision in In re Todd, 208 Ind. I68, I93 N.E. 865 (I935)? That they are in force is suggested in Chattin, op. cit. supra note 9 at 515 . The problem is presented in but a few instances (hereafter designated by this note number 59), as in most cases in which an amendment failed of adoption, it was later adopted in a special election. Notice particularly the income tax amendments submitted in 1926 and 1932 . They were identical and permitted a levy on income "from whatever source derived." The amendment is probably valid today, as of I926, the date when a majority of affirmative over negative votes was first obtained, rather than as of I932. Indiana has had a gross income tax since r933, Ind. Stat. Ann. (Burns, r933) \& 64-260r, but has not enacted a tax levy upon net incomes.

${ }^{60}$ Same amendment proposed at the general election of 1900 .

6ז Same amendment proposed in I900 and I906.

62 Information is lacking as to the total vote at this election. 
TABLE 2-Continued

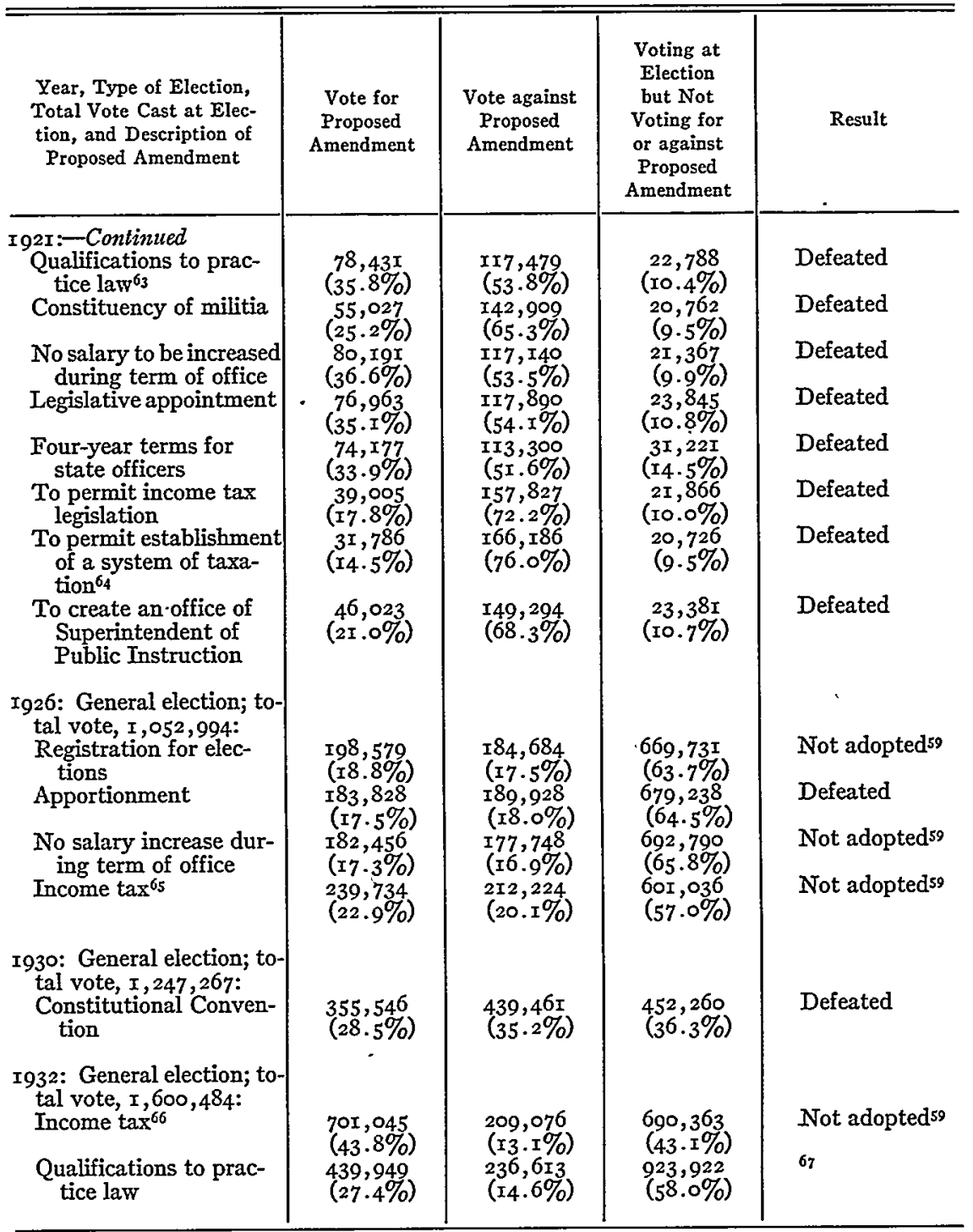

${ }_{63}$ Same amendment submitted in 1900, x906, and r910.

${ }^{64}$ An amendment to permit income tax legislation and other similar types of tax legislation. It is somewhat broader than the amendment immediately preceding.

${ }^{65}$ Same as the one defeated at the special election in r92r.

${ }^{66}$ Same as in r92I and I926. Vote in I926, as well as that in 1932 , probably made this amendment effective, under the decision in the Todd case. See note 59 supra.

${ }^{67}$ Same amendment proposed in I900, rgo6, 1910, and I92I. It was declared adopted by the Todd case. 
TABLE 2-Continuted

\begin{tabular}{|c|c|c|c|c|}
\hline $\begin{array}{l}\text { Year, Type of Election, } \\
\text { Total Vote Cast at Elec- } \\
\text { tion, and Description of } \\
\text { Proposed Amendment }\end{array}$ & $\begin{array}{l}\text { Vote for } \\
\text { Proposed } \\
\text { Amendment }\end{array}$ & $\begin{array}{l}\text { Vote against } \\
\text { Proposed } \\
\text { Amendment }\end{array}$ & $\begin{array}{l}\text { Voting at } \\
\text { Election } \\
\text { but Not } \\
\text { Voting for } \\
\text { or against } \\
\text { Proposed } \\
\text { Amendment }\end{array}$ & Result \\
\hline $\begin{array}{l}\text { 1936: General election; to- } \\
\text { tal vote, I,643,820: } \\
\text { Militia to include ne- } \\
\text { groes }\end{array}$ & $\begin{array}{l}426,031 \\
(26.0 \%)\end{array}$ & $\begin{array}{l}398,201 \\
(24.2 \%)\end{array}$ & $\begin{array}{l}819,588 \\
(49.8 \%)\end{array}$ & Adopted $^{68}$ \\
\hline $\begin{array}{l}\text { I940: Total vote, } \\
\text { I,790, ro9: } \\
\text { Elimination of double } \\
\text { liability for bank } \\
\text { stockholders }\end{array}$ & $\begin{array}{l}355,578 \\
(x 9.9 \%)\end{array}$ & $\begin{array}{l}267,589 \\
(14.9 \%)\end{array}$ & $\begin{array}{r}I, I 66,942 \\
(65.2 \%)\end{array}$ & Adopted ${ }^{68}$ \\
\hline $\begin{array}{l}\text { Corporate shareholder's } \\
\text { liability } \\
\text { Elimination of require- } \\
\text { ment to renew bank } \\
\text { charters }\end{array}$ & $\begin{array}{l}344,262 \\
(19.2 \%) \\
325,280 \\
(18.2 \%)\end{array}$ & $\begin{array}{l}229,370 \\
(12.8 \%) \\
242,846 \\
(13.6 \%)\end{array}$ & $\begin{array}{l}\mathrm{I}, 2 \mathrm{2} 6,477 \\
(68.0 \%) \\
\mathrm{I}, 221,983 \\
(68.2 \%)\end{array}$ & $\begin{array}{l}\text { Adopted }^{68} \\
\text { Adopted }^{68}\end{array}$ \\
\hline
\end{tabular}

TABLE 3

\begin{tabular}{r|c|c|c|c}
\hline \hline & Total & Adopted & Not Adopted & Defeated \\
\hline $\begin{array}{c}\text { General election....... } \\
\text { Special election........ }\end{array}$ & 23 & None & $20^{69}$ & 3 \\
Grand total....... & 46 & II & None & I2 \\
\hline
\end{tabular}

the voters have always provided that the amendment shall be submitted on a ballot separate from that carrying the names of candidates for office. ${ }^{70}$

An act passed in $\mathrm{Ig}^{\mathrm{II} \mathrm{I}^{7 x}}$ provides that political parties may take official action upon constitutional amendments, and that such action will be printed upon the official ballot below the names of the parties' candidates

${ }^{68}$ Adopted by virtue of the change in the method of amendment resulting from the Todd decision. But for this decision they would not have been adopted.

${ }^{69}$ This number includes five amendments, one of which was given effect by the decision in In re Todd, and four others which were voted upon after the decision in that case and so are effective by virtue thereof. None of these would have been adopted had the Indiana rule not been changed by that decision. Also included are four amendments, one of which was submitted twice, which were voted upon prior to the Todd decision, and were regarded at the time they were voted upon as not having been adopted, but which are now probably effective as a result of such decision. See note 59 supra.

${ }^{70}$ Phillipp, note 55 supra.

$7 x$ Ind. Stat. Ann. (Burns, I933) c. 12, \$§ 29-I203-29-1207. 
for office. It provides that a vote in the party circle shall be counted for or against the amendment according to the party action taken. The proposed amendment, with an opportunity to vote in the affirmative or negative, is also to be printed elsewhere on the ballot, and a voter may, by voting separately upon the amendment, have his vote counted differently from the position taken by his party. No political party has ever availed itself of this power, conferred by the act of IgII, to have its position on an amendment printed in its column on the ballot. ${ }^{72}$ In view of the decision in the Todd case it is difficult to visualize why Indiana retains this party circle law. It is no longer needed and it could be used for an undesirable partisan purpose.

Minnesota - The method of ratifying constitutional amendments in Minnesota was changed by a constitutional amendment in 1898 . Prior thereto, amendments were ratified by the vote of a majority of those voting thereon. After the amendment of 1898 a majority of all votes cast for any purpose at the general election became necessary in order to obtain ratification. ${ }^{73} \mathrm{It}$ is interesting to note that under the rule adopted by the amendment of $\mathrm{x} 898$, that amendment itself would never have become effective because, while it received 68 per cent of the votes cast thereon, still it obtained only 27 per cent of all votes cast at the general election at which it was submitted to the voters. ${ }^{74}$

Prior to the change in 1898 there had been proposed to the people of Minnesota a total of sixty-six amendments, of which forty-eight were adopted. ${ }^{75}$ Table 4 shows the varied experience which Minnesota has had with such amendments as have been proposed since the change was made.

The experience in constitutional amending as presented by Table 4 is far from satisfactory. It shows the struggle of a great commonwealth to keep its constitutional machinery adapted to ever changing problems. Prior to the change in the amending system in 1898,73 per cent of all proposed amendments were adopted as against 27 per cent defeated. Of the seventy-six amendments submitted to the electorate in the four decades between 1898 and $x 938$, only two, or less than 3 per cent of the total, were actually defeated by a preponderance of negative votes on the

72 Phillipp, note 55 supra.

73 Anderson, op. cit. supra note 8. The usual history has been reversed in Minnesota. Most changes in the method of constitutional amendment have favored greater flexibility.

${ }^{74}$ Information received from Mr. M. Holm, Secretary of State, St. Paul, Minnesota. For a table of amendments voted on between $\mathrm{r} 890$ and $\mathrm{r} 898$ see note 99 infra.

75 Anderson, op. cit. supra note 8. 
TABLE $4^{76}$

\begin{tabular}{|c|c|c|c|c|}
\hline $\begin{array}{c}\text { Year, Total Vote } \\
\text { Cast at Election, } 77 \text { and } \\
\text { Description of Proposed } \\
\text { Amendment }\end{array}$ & $\begin{array}{l}\text { Vote for } \\
\text { Proposed } \\
\text { Amendment }\end{array}$ & $\begin{array}{l}\text { Vote against } \\
\text { Proposed } \\
\text { Amendment }\end{array}$ & $\begin{array}{l}\text { Voting at } \\
\text { Election but } \\
\text { Not Voting for } \\
\text { or against } \\
\text { Proposed } \\
\text { Amendment }\end{array}$ & Result \\
\hline $\begin{array}{l}\text { I900: Total vote for Gov- } \\
\text { ernor, 3I4,I8I (for Presi- } \\
\text { dent, 3I6,3II): } \\
\text { To permit school funds to } \\
\text { be invested in munici- } \\
\text { pal bonds }\end{array}$ & $\begin{array}{l}\text { I08,68I } \\
(34.6 \%)\end{array}$ & $\begin{array}{l}30,160 \\
(9.6 \%)\end{array}$ & $\begin{array}{l}I 75,340 \\
(55.8 \%)\end{array}$ & Not adopted \\
\hline $\begin{array}{l}\text { I902: } 2^{8} \text { Total vote } 276,071: \\
\text { To permit school funds to } \\
\text { be invested in munici- } \\
\text { pal bonds }\end{array}$ & $\begin{array}{l}1 \times 6,766 \\
(42.3 \%)\end{array}$ & $\begin{array}{l}20,777 \\
(7.5 \%)\end{array}$ & $\begin{array}{l}138,528 \\
(50.2 \%)\end{array}$ & Not adopted \\
\hline $\begin{array}{l}\text { State tax for road and } \\
\text { bridge fund }\end{array}$ & $\begin{array}{l}\operatorname{Ir} 4,969 \\
(4 \mathrm{I} .6 \%)\end{array}$ & $\begin{array}{l}23,948 \\
(8.7 \%)\end{array}$ & $\begin{array}{l}I 37,154 \\
(49.7 \%)\end{array}$ & Not adopted \\
\hline $\begin{array}{l}\text { Franchise and income } \\
\text { taxation }\end{array}$ & $\begin{array}{l}\text { I24, } 584 \\
(45.1 \%)\end{array}$ & $\begin{array}{l}21,251 \\
(7.7 \%)\end{array}$ & $\begin{array}{l} \pm 30,236 \\
(47.2 \%)\end{array}$ & Not adopted \\
\hline $\begin{array}{l}\text { 1904: Total vote } 322,692: \\
\text { To permit school funds } \\
\text { to be invested in mu- } \\
\text { nicipal bonds } 79\end{array}$ & $\begin{array}{l}190,718 \\
(59.1 \%)\end{array}$ & $\begin{array}{l}39,334 \\
(12.2 \%)\end{array}$ & $\begin{array}{l}92,640 \\
(28.7 \%)\end{array}$ & Adopted \\
\hline $\begin{array}{l}\text { Repealing requirement of } \\
\text { indictment by grand } \\
\text { jury }\end{array}$ & $\begin{array}{l}164,555 \\
(51.0 \%)\end{array}$ & $\begin{array}{l}52,152 \\
(16.2 \%)\end{array}$ & $\begin{array}{l}\text { I05, } 985 \\
(32.8 \%)\end{array}$ & Adopted \\
\hline
\end{tabular}

${ }^{76}$ The data in this table has been taken from the Annual Legislative Manuals issued by the Secretary of State of the State of Minnesota, and from Anderson and Lobb, History of the Constitution of Minnesota 278-85 (I92I). In I902, I904, I906, I908, and I910 the total number of women who voted is set forth; but the number was always less than 20,000 . They appear to have voted in certain counties only. In later years, but before I920, they voted to some extent but the total vote is not stated. This female vote is not included.

77 The elections mentioned in this table were general elections. Hereafter, unless specified otherwise, only general elections will be dealt with. Indiana, which has already been considered, and Oklahoma are the only states being considered, in which constitutional amendments have been submitted to the voters at special elections.

${ }_{78}^{8}$ In rgo2 and 1904 a proposition to increase the gross earnings tax on railroads was submitted, but it is not clear whether it was a constitutional amendment. The totals on such proposition were:

\begin{tabular}{|c|c|c|c|c|}
\hline Year & Afirmative & Negative & Not Voting & Results \\
\hline $\begin{array}{l}1902 . . . . \\
1904 \ldots . . .\end{array}$ & $\begin{array}{l}130,522 \\
(47,3 \%) \\
240,578 \\
(74.6 \%)\end{array}$ & $\begin{array}{l}15,033 \\
(5.4 \%) \\
30,518 \\
(9.5 \%)\end{array}$ & $\begin{array}{c}130,516 \\
(47.3 \%) \\
51,596 \\
(15.9 \%)\end{array}$ & $\begin{array}{l}\text { Not adopted } \\
\text { Adopted }\end{array}$ \\
\hline
\end{tabular}

79 Previously submitted in r900 and r9oz. 
TABLE 4-Continued

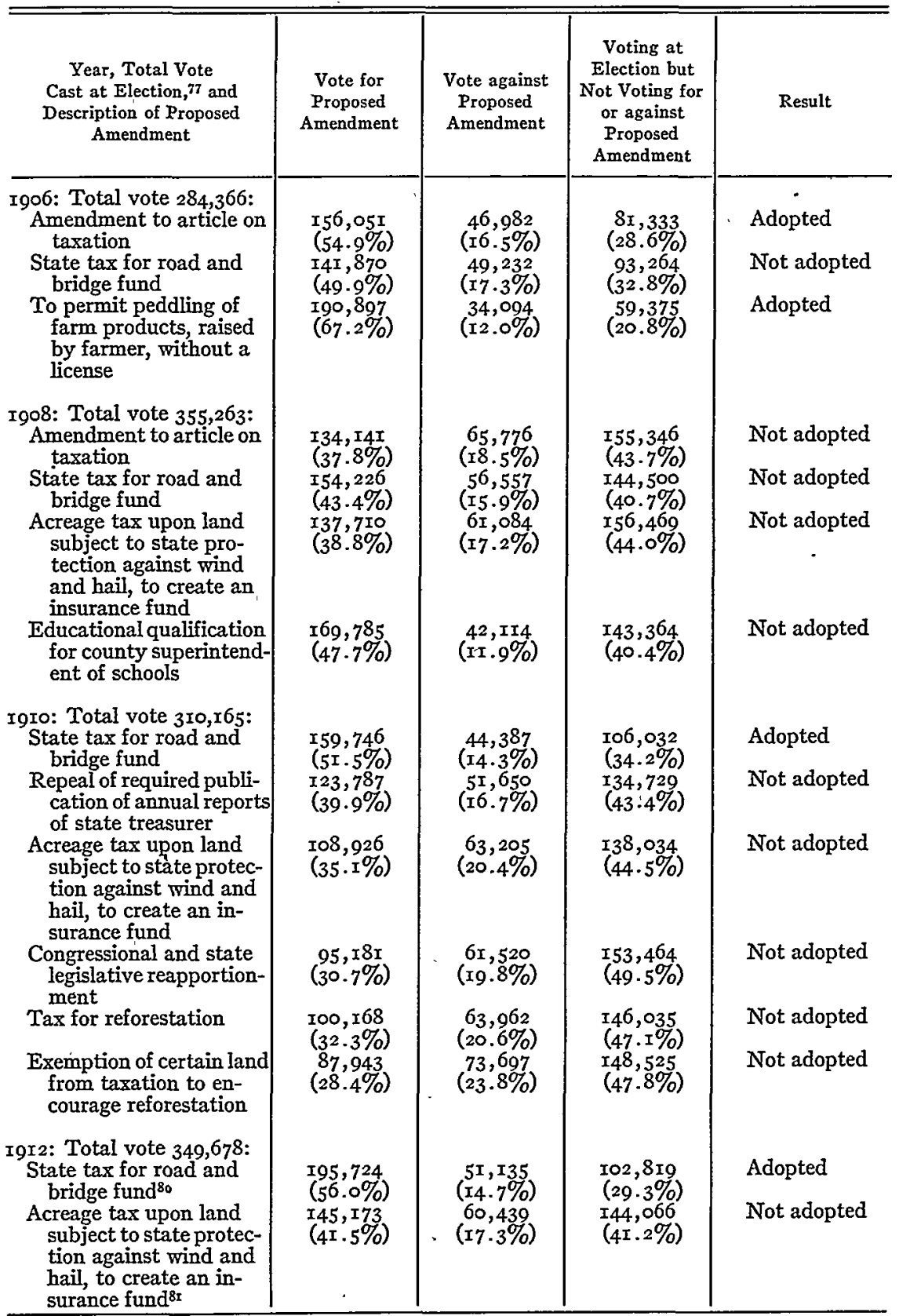

${ }^{80}$ Previously submitted in Igo2, 1906, 1908, and rgro.

8x Previously submitted in r908 and I9Io. 
TABLE 4-Continned

\begin{tabular}{|c|c|c|c|c|}
\hline $\begin{array}{c}\text { Year, Total Vote } \\
\text { Cast at Election,77 and } \\
\text { Description of Proposed } \\
\text { Amendment }\end{array}$ & $\begin{array}{l}\text { Vote for } \\
\text { Proposed } \\
\text { Amendment }\end{array}$ & $\begin{array}{l}\text { Vote against } \\
\text { Proposed } \\
\text { Amendment }\end{array}$ & $\begin{array}{l}\text { Voting at } \\
\text { Election but } \\
\text { Not Voting for } \\
\text { or against } \\
\text { Proposed } \\
\text { Amendment }\end{array}$ & ResuIt \\
\hline \multicolumn{5}{|l|}{ I9I2:-Continued } \\
\hline $\begin{array}{l}\text { Increase of gross income } \\
\text { tax on railroads }\end{array}$ & $\begin{array}{l}x 84,6 x_{2} \\
(52.9 \%)\end{array}$ & $\begin{array}{l}4 \mathrm{I}, \mathrm{I} 3 \mathrm{O} \\
(\mathrm{II} .9 \%)\end{array}$ & $\begin{array}{l}\text { I23,936 } \\
(35.2 \%)\end{array}$ & Adopted \\
\hline $\begin{array}{l}\text { To authorize loan of } \\
\text { school funds upon im- } \\
\text { proved farm lands }\end{array}$ & $\begin{array}{l}x 68,440 \\
(48.2 \%)\end{array}$ & $\begin{array}{c}39,483 \\
(\mathrm{II.x \% )})\end{array}$ & $\begin{array}{l}\text { r } 41,755 \\
(40.7 \%)\end{array}$ & Not adopted \\
\hline $\begin{array}{l}\text { To allow municipal cor- } \\
\text { porations to frame } \\
\text { their own charters }\end{array}$ & $\begin{array}{l}I 57,086 \\
(45.0 \%)\end{array}$ & $\begin{array}{c}4 \mathrm{I}, 97 \mathrm{I} \\
(\mathrm{I} 2.0 \%)\end{array}$ & $\begin{array}{l}I 50,62 I \\
(43.0 \%)\end{array}$ & Not adopted \\
\hline $\begin{array}{l}\text { Educational qualifica- } \\
\text { tion for superintendent } \\
\text { of county schools }\end{array}$ & $\begin{array}{l}I 67,983 \\
(47.9 \%)\end{array}$ & $\begin{array}{c}36,584 \\
(x 0.6 \%)\end{array}$ & $\begin{array}{l}\mathrm{r}_{45, \mathrm{III}} \\
(4 \mathrm{I} .5 \%)\end{array}$ & Not adopted \\
\hline $\begin{array}{l}\text { Senatorial reapportion- } \\
\text { ment }\end{array}$ & $\begin{array}{l}\text { I22, } 457 \\
(35.0 \%)\end{array}$ & $\begin{array}{l}77,187 \\
(22.0 \%)\end{array}$ & $\begin{array}{l}r 50,034 \\
(43.0 \%)\end{array}$ & Not adopted \\
\hline \multicolumn{5}{|l|}{ I9I4: Total vote $356,906:$} \\
\hline Initiative and referendum & $I 68,004$ & 41,577 & 147,325 & Not adopted \\
\hline $\begin{array}{l}\text { To increase supreme } \\
\text { judges from four to six } \\
\text { and to forbid supreme } \\
\text { court from declaring } \\
\text { act unconstitutional ex- } \\
\text { cept by concurrence of } \\
\text { five out of six judges }\end{array}$ & $\begin{array}{l}(47.070) \\
127,352 \\
(35.6 \%)\end{array}$ & $\begin{array}{l}68,886 \\
(\mathrm{Ig} .4 \%)\end{array}$ & $\begin{array}{l}(41.2 \%) \\
\text { I60,668 } \\
(45.0 \%)\end{array}$ & Not adopted \\
\hline $\begin{array}{l}\text { Revolving fund for } \\
\text { roads, etc., from school } \\
\text { and swamp land fund }\end{array}$ & $\begin{array}{l}\mathrm{I} 62,95 \mathrm{I} \\
(45.7 \%)\end{array}$ & $\begin{array}{l}47,906 \\
(\mathrm{x} 3.4 \%)\end{array}$ & $\begin{array}{l}\text { I } 46,049 \\
(40.9 \%)\end{array}$ & Not adopted \\
\hline $\begin{array}{l}\text { Repeal of requirement of } \\
\text { of publication of an- } \\
\text { nual reports of state } \\
\text { treasurer }^{82}\end{array}$ & $\begin{array}{l}\text { I3I, 213 } \\
(36.8 \%)\end{array}$ & $\begin{array}{c}58,827 \\
(16.5 \%)\end{array}$ & $\begin{array}{l}166,866 \\
(46.7 \%)\end{array}$ & Not adopted \\
\hline $\begin{array}{l}\text { To authorize loan of } \\
\text { school funds on im- } \\
\text { proved farm lands }\end{array}$ & $\begin{array}{l}159,531 \\
(44.7 \%)\end{array}$ & $\begin{array}{l}38,145 \\
(10.6 \%)\end{array}$ & $\begin{array}{l}159,230 \\
(44.7 \%)\end{array}$ & Not adopted \\
\hline $\begin{array}{l}\text { Increased term for pro- } \\
\text { bate judges }\end{array}$ & $\begin{array}{l}\text { I } 28,60 \mathrm{I} \\
(36.3 \%)\end{array}$ & $\begin{array}{c}64,2 \pi 4 \\
(17.7 \%)\end{array}$ & $\begin{array}{l}I 64,09 I \\
(46.0 \%)\end{array}$ & Not adopted \\
\hline $\begin{array}{l}\text { Senatorial reapportion- } \\
\text { ment }^{83}\end{array}$ & $\begin{array}{l}98,144 \\
(27.6 \%)\end{array}$ & $\begin{array}{l}84,436 \\
(23.6 \%)\end{array}$ & $\begin{array}{l}174,326 \\
(48.8 \%)\end{array}$ & Not adopted \\
\hline Tree bounties & $\begin{array}{l}108,352 \\
(30.9 \%)\end{array}$ & $\begin{array}{l}63,782 \\
(\mathrm{r} .3 \%)\end{array}$ & $\begin{array}{l}184,772 \\
(51.8 \%)\end{array}$ & Not adopted \\
\hline $\begin{array}{l}\text { Use of state lands for } \\
\text { state forests }\end{array}$ & $\begin{array}{l}178,954 \\
(50.1 \%)\end{array}$ & $\begin{array}{l}44,033 \\
(12.4 \%)\end{array}$ & $\begin{array}{l}133,919 \\
(37.5 \%)\end{array}$ & Adopted \\
\hline Recall of public officials & $\begin{array}{l}\text { I } 39,80 \mathrm{I} \\
(39.3 \%)\end{array}$ & $\begin{array}{l}44,96 \mathrm{~T} \\
(\mathrm{I} 2.2 \%)\end{array}$ & $\begin{array}{l}\text { I72,I } 44 \\
(48.5 \%)\end{array}$ & Not adopted \\
\hline $\begin{array}{l}\text { Taxation of dogs to com- } \\
\text { pensate for dog in- } \\
\text { juries }\end{array}$ & $\begin{array}{l}136,671 \\
(38.4 \%)\end{array}$ & $\begin{array}{l}59,786 \\
(x 6.6 \%)\end{array}$ & $\begin{array}{l}160,449 \\
(45.0 \%)\end{array}$ & Not adopted \\
\hline
\end{tabular}

82 Previously submitted in rgı.

${ }^{8}$ Previously submitted in rgro and Igr2. 
TABLE 4-Contimued

\begin{tabular}{|c|c|c|c|c|}
\hline $\begin{array}{c}\text { Year, Total Vote } \\
\text { Cast at Election, } 77 \text { and } \\
\text { Description of Proposed } \\
\text { Amendment }\end{array}$ & $\begin{array}{l}\text { Vote for } \\
\text { Proposed } \\
\text { Amendment }\end{array}$ & $\begin{array}{c}\text { Vote against } \\
\text { Proposed } \\
\text { Amendment }\end{array}$ & $\begin{array}{l}\text { Voting at } \\
\text { Election but } \\
\text { Not Voting for } \\
\text { or against } \\
\text { Proposed } \\
\text { Amendment }\end{array}$ & Resuit \\
\hline $\begin{array}{l}\text { I9r6: Total vote } 4 \text { I6,2I5: } \\
\text { Revolving fund for roads, } \\
\text { etc., from school and } \\
\text { swamp lands fund }\end{array}$ & $\begin{array}{l}240,975 \\
(58.0 \%)\end{array}$ & $\begin{array}{l}58, \text { roo } \\
(14.0 \%)\end{array}$ & $\begin{array}{l}\text { II } 7, \text { I } 40 \\
(28.0 \%)\end{array}$ & Adopted \\
\hline $\begin{array}{l}\text { To permit loan of school } \\
\text { funds on improved } \\
\text { farm lands }{ }^{84}\end{array}$ & $\begin{array}{l}211,529 \\
(50.7 \%)\end{array}$ & $\begin{array}{c}56,147 \\
(13 \cdot 5 \%)\end{array}$ & $\begin{array}{l}\tau 48,539 \\
(35.8 \%)\end{array}$ & Adopted \\
\hline $\begin{array}{l}\text { To authorize protection } \\
\text { for public waters }\end{array}$ & $\begin{array}{l}\text { I83,597 } \\
(44.0 \%)\end{array}$ & $\begin{array}{l}64,255 \\
(15.8 \%)\end{array}$ & $\begin{array}{l}x 68,363 \\
(40.2 \%)\end{array}$ & Not adopted \\
\hline $\begin{array}{l}\text { To increase number of } \\
\text { judges on supreme } \\
\text { court }\end{array}$ & $\begin{array}{l}\mathrm{r} 30,363 \\
(31.4 \%)\end{array}$ & $\begin{array}{l}\text { I08,002 } \\
(26.0 \%)\end{array}$ & $\begin{array}{l}177,850 \\
(42.6 \%)\end{array}$ & Not adopted \\
\hline $\begin{array}{l}\text { To permit approval by } \\
\text { governor of single items } \\
\text { in appropriation bills }\end{array}$ & $\begin{array}{l}\text { 工36,700 } \\
(32.9 \%)\end{array}$ & $\begin{array}{c}83,324 \\
(20.3 \%)\end{array}$ & $\begin{array}{l}\text { r96, rgr } \\
(46.8 \%)\end{array}$ & Not adopted \\
\hline $\begin{array}{l}\text { To allow taking of private } \\
\text { property for drainage } \\
\text { purposes }\end{array}$ & $\begin{array}{l}\text { I32,74I } \\
(3 \mathrm{I} .8 \%)\end{array}$ & $\begin{array}{l}97,432 \\
(23 \cdot 5 \%)\end{array}$ & $\begin{array}{l}\mathrm{I86,042} \\
(44 \cdot 7 \%)\end{array}$ & Not adopted \\
\hline $\begin{array}{l}\text { Initiative and referen- } \\
\text { dum }^{8 s}\end{array}$ & $\begin{array}{l}I 87,7 x \mathrm{Ir} \\
(45.0 \%)\end{array}$ & $\begin{array}{l}5 x, 544 \\
(x 2.5 \%)\end{array}$ & $\begin{array}{l}\mathrm{x} 76,960 \\
(42.5 \%)\end{array}$ & Not adopted \\
\hline $\begin{array}{l}\text { Increase of terms of pro- } \\
\text { bate judges }\end{array}$ & $\begin{array}{l}186,847 \\
(44.8 \%)\end{array}$ & $\begin{array}{l}72,36 \mathrm{r} \\
(\mathrm{I} 7.5 \%)\end{array}$ & $\begin{array}{l}\text { I57,007 } \\
(37.7 \%)\end{array}$ & Not adopted \\
\hline $\begin{array}{l}\text { I9I8: Total vote } 380,604: \\
\text { Prohibition }\end{array}$ & $\begin{array}{l} \pm 89,6 \pm 4 \\
(49 \cdot 7 \%)\end{array}$ & $\begin{array}{l}\mathrm{I} 73,665 \\
(45.8 \%)\end{array}$ & $\begin{array}{l}\mathrm{r} 7,325 \\
(4.5 \%)\end{array}$ & Not adopted \\
\hline $\begin{array}{l}\text { I920: Total vote } 797,945: \\
\text { Taxation of motor ve- } \\
\text { hicles to provide a } \\
\text { trunk highway system }\end{array}$ & $\begin{array}{l}526,936 \\
(66.0 \%)\end{array}$ & $\begin{array}{l}x 99,603 \\
(25.0 \%)\end{array}$ & $\begin{array}{l}71,406 \\
(9.0 \%)\end{array}$ & Adopted \\
\hline $\begin{array}{l}\text { Increase of terms of } \\
\text { probate judges }\end{array}$ & $\begin{array}{l}446,959 \\
(56.0 \%)\end{array}$ & $\begin{array}{l}\mathrm{I} 7 \mathrm{I}, 4 \mathrm{I} 4 \\
(2 \mathrm{I} .5 \%)\end{array}$ & $\begin{array}{l}\text { I } 79,572 \\
(22.5 \%)\end{array}$ & Adopted \\
\hline $\begin{array}{l}\text { Amendment of tax ar- } \\
\text { ticle of constitution, } \\
\text { permitting a progres- } \\
\text { sive income tax }\end{array}$ & $\begin{array}{l}33 \mathrm{I}, \mathrm{IOS} \\
(4 \mathrm{I} .5 \%)\end{array}$ & $\begin{array}{l}217,558 \\
(27.0 \%)\end{array}$ & $\begin{array}{l}249,282 \\
(31.5 \%)\end{array}$ & Not adopted \\
\hline $\begin{array}{l}\text { 1922: Information as to } \\
\text { total vote not available: } 87 \\
\text { State credit to agricul- } \\
\text { ture }\end{array}$ & 534,310 & 73,917 & & Adopted \\
\hline Tax on mining & 474,697 & 9I, OII & & Adopted \\
\hline
\end{tabular}

84 Previously submitted in Igr2 and rgr4.

${ }_{55}$ Previously submitted in IgI $_{4}$.

${ }^{86}$ Previously submitted in 1914 and Igr6.

${ }^{87} \mathrm{Data}$ in the usual yearbook was not available for 1922 . Information was obtained from a private file in the Library of Congress and from I 2 National Municipal Review 201 (I923). The total vote at the election was not disclosed in these sources. But in the National Municipal Review it is stated that the vote for governor was 685,095 and that the two propositions received aggregates of 88 and 82 per cent respectively of the vote for governor, which aggregates include both affirmative and negative votes. 
TABLE 4-Continued

\begin{tabular}{|c|c|c|c|c|}
\hline $\begin{array}{c}\text { Year, Total Vote } \\
\text { Cast at Election, } 77 \text { and } \\
\text { Description of Proposed } \\
\text { Amendment }\end{array}$ & $\begin{array}{l}\text { Vote for } \\
\text { Proposed } \\
\text { Amendment }\end{array}$ & $\begin{array}{l}\text { Vote against } \\
\text { Proposed } \\
\text { Amendment }\end{array}$ & $\begin{array}{l}\text { Voting at } \\
\text { Election but } \\
\text { Not Voting for } \\
\text { or against } \\
\text { Proposed } \\
\text { Amendment }\end{array}$ & Result \\
\hline \multirow{2}{*}{$\begin{array}{l}\text { I924: Total vote } 869,15 \mathrm{I}: \\
\text { Tax on gasoline sales for } \\
\text { trunk highway system } \\
\text { Change of requirements } \\
\text { for publication in } \\
\text { amending municipal } \\
\text { charters }\end{array}$} & \multirow{2}{*}{$\begin{array}{l}520,769 \\
(60.0 \%) \\
246,414 \\
(28.4 \%)\end{array}$} & \multirow{2}{*}{$\begin{array}{l}197,455 \\
(22.7 \%) \\
200,391 \\
(23.0 \%)\end{array}$} & \multirow{2}{*}{$\begin{array}{l}150,927 \\
(17.3 \%) \\
422,346 \\
(48.6 \%)\end{array}$} & \multirow{2}{*}{$\begin{array}{l}\text { Adopted } \\
\text { Not adopted }\end{array}$} \\
\hline & & & & \\
\hline $\begin{array}{l}\text { State-owned grain ele- } \\
\text { vator }\end{array}$ & \multirow{3}{*}{$\begin{array}{l}253,732 \\
(29.2 \%) \\
428,4 \% 7 \\
(49.4 \%) \\
460,965 \\
(53.3 \%)\end{array}$} & \multirow{3}{*}{$\begin{array}{l}257,492 \\
(29.6 \%) \\
143,977 \\
(16.5 \%) \\
143,518 \\
(16.5 \%)\end{array}$} & \multirow{3}{*}{$\begin{array}{l}357,927 \\
(41.2 \%) \\
296,767 \\
(34.1 \%) \\
264,668 \\
(30.2 \%)\end{array}$} & Defeated \\
\hline $\begin{array}{l}\text { Authorizing laws encour- } \\
\text { aging reforestation }\end{array}$ & & & & Not adopted \\
\hline $\begin{array}{l}\text { Authorizing forest-fire } \\
\text { control measures }\end{array}$ & & & & Adopted \\
\hline \multicolumn{4}{|l|}{ 1926: Total vote $722,78 \mathrm{r}:$} & \multirow[b]{2}{*}{ Not adopted } \\
\hline $\begin{array}{l}\text { To increase number of } \\
\text { judges on supreme } \\
\text { court }\end{array}$ & $\begin{array}{l}33 x, 964 \\
(45.9 \%)\end{array}$ & $\begin{array}{l}x 48,784 \\
(20.7 \%)\end{array}$ & $\begin{array}{l}242,033 \\
(33.4 \%)\end{array}$ & \\
\hline $\begin{array}{l}\text { Authorizing laws encour- } \\
\text { aging reforestation }\end{array}$ & $\begin{array}{l}383,003 \\
(53.0 \%)\end{array}$ & $\begin{array}{l}x 27,592 \\
(x 7.8 \%)\end{array}$ & $\begin{array}{l}212,186 \\
(29.2 \%)\end{array}$ & Adopted \\
\hline $\begin{array}{l}\text { Authorizing legislation to } \\
\text { limit the liability of } \\
\text { stockholders in corpo- } \\
\text { rations }\end{array}$ & $\begin{array}{l}323,322 \\
(44.8 \%)\end{array}$ & $\begin{array}{l}\mathrm{I} 40,422 \\
(\mathrm{I} 9.4 \%)\end{array}$ & $\begin{array}{l}259,037 \\
(35.8 \%)\end{array}$ & Not adopted \\
\hline & 542,796 & \multirow{2}{*}{$\begin{array}{l}346,109 \\
(32.3 \%)\end{array}$} & \multirow{2}{*}{$\begin{array}{l}\mathrm{r8}, 369 \\
(16.9 \%)\end{array}$} & \multirow[t]{2}{*}{ Adopted } \\
\hline $\begin{array}{l}\text { twreen the "Road and } \\
\text { Bridge Fund" and the } \\
\text { "Trunk Highway } \\
\text { Fund" }\end{array}$ & $(50.8 \%)$ & & & \\
\hline $\begin{array}{l}\text { Authorizing legislation to } \\
\text { limit the liability of } \\
\text { stockholders in corpo- } \\
\text { rations }\end{array}$ & $\begin{array}{l}506,065 \\
(47.3 \%)\end{array}$ & $\begin{array}{l}223,725 \\
(20.9 \%)\end{array}$ & $\begin{array}{l}340,484 \\
(31.8 \%)\end{array}$ & Not adopted \\
\hline \multirow{2}{*}{$\begin{array}{l}\text { 1930: Total vote } 828,401: \\
\text { Authorizing legislation to } \\
\text { limit the liability of } \\
\text { stockholders in corpo- } \\
\text { rations }^{88}\end{array}$} & $486,8 \mathrm{r} 8$ & $I 35,345$ & 206,238 & \multirow[t]{2}{*}{ Adopted } \\
\hline & $(58.8 \%)$ & (16.3\%) & $(24.9 \%)$ & \\
\hline $\begin{array}{l}\text { To increase number of } \\
\text { judges on Supreme } \\
\text { Court }\end{array}$ & $\begin{array}{l}428,013 \\
(51.7 \%)\end{array}$ & $\begin{array}{l}\text { I30,833 } \\
\left({ }_{5} 5.8 \%\right)\end{array}$ & $\begin{array}{l}269,555 \\
(32.5 \%)\end{array}$ & Adopted \\
\hline $\begin{array}{l}\text { Authorizing exchange of } \\
\text { state lands for United } \\
\text { States lands }\end{array}$ & $\begin{array}{l}378,716 \\
(45.7 \%)\end{array}$ & $\begin{array}{l}\mathrm{I} 74,23 \mathrm{I} \\
(2 \mathrm{I} .0 \%)\end{array}$ & $\begin{array}{l}275,454 \\
(33 \cdot 3 \%)\end{array}$ & Not adopted \\
\hline
\end{tabular}

${ }^{88}$ Previously submitted in 1926 and 1928.

89 Previously submitted in I9x6 and I926. 


\begin{tabular}{|c|c|c|c|c|}
\hline $\begin{array}{l}\text { Year, Total Vote } \\
\text { Cast at Election, } 77 \text { and } \\
\text { Description of Proposed } \\
\text { Amendment }\end{array}$ & $\begin{array}{l}\text { Vote for } \\
\text { Proposed } \\
\text { Amendment }\end{array}$ & $\begin{array}{c}\text { Vote against } \\
\text { Proposed } \\
\text { Amendment }\end{array}$ & $\begin{array}{l}\text { Voting at } \\
\text { Election but } \\
\text { Not Voting for } \\
\text { or against } \\
\text { Proposed } \\
\text { Amendment }\end{array}$ & Result \\
\hline $\begin{array}{l}\text { I932: Total vote } \mathrm{I}, 054,203 \text { : } \\
\text { Authorizing progressive } \\
\text { income tax }\end{array}$ & $\begin{array}{l}420,052 \\
(30.8 \%)\end{array}$ & 409,924 & 224,227 & Not adopted \\
\hline $\begin{array}{l}\text { Amending tax power as to } \\
\text { motor vehicles }\end{array}$ & $\begin{array}{l}537,292 \\
(51.0 \%)\end{array}$ & $\begin{array}{l}227,634 \\
(21.5 \%)\end{array}$ & $\begin{array}{l}289,277 \\
(27.5 \%)\end{array}$ & Adopted \\
\hline $\begin{array}{l}\text { Authorizing exchange of } \\
\text { state lands for United } \\
\text { State lands }\end{array}$ & $\begin{array}{l}433,913 \\
(4 \mathrm{r} .2 \%)\end{array}$ & $\begin{array}{l}258,257 \\
(24.5 \%)\end{array}$ & $\begin{array}{l}362,0.33 \\
(34.3 \%)\end{array}$ & Not adopted \\
\hline $\begin{array}{l}\text { Authorizing taxation of } \\
\text { land acquired through } \\
\text { state's rural credit } \\
\text { system }\end{array}$ & $\begin{array}{l}468, \text { IOI } \\
(44.5 \%)\end{array}$ & $\begin{array}{l}26 \mathrm{x}, 856 \\
(24.8 \%)\end{array}$ & $\begin{array}{l}324,246 \\
(30.7 \%)\end{array}$ & Not adopted \\
\hline $\begin{array}{l}\text { 1934: Total vote } 1,064,332: \\
\text { Changed routes for } \\
\text { trunk highway system }\end{array}$ & $\begin{array}{l}509,074 \\
(47.9 \%)\end{array}$ & $\begin{array}{l}279,877 \\
(26.3 \%)\end{array}$ & $\begin{array}{l}275,38 \mathrm{x} \\
(25.8 \%)\end{array}$ & Not adopted \\
\hline $\begin{array}{l}\text { Authorizing taxation of } \\
\text { land acquired through } \\
\text { state's rural credit } \\
\text { system } \%\end{array}$ & $\begin{array}{l}496,017 \\
(46.7 \%)\end{array}$ & $\begin{array}{l}2 I 5,623 \\
(20.3 \%)\end{array}$ & $\begin{array}{l}352,692 \\
(33.0 \%)\end{array}$ & Not adopted \\
\hline $\begin{array}{l}\text { To exempt household } \\
\text { goods and farm equip- } \\
\text { ment from personal }\end{array}$ & $\begin{array}{l}630,125 \\
(59 \cdot 3 \%)\end{array}$ & $\begin{array}{l}\mathrm{I8I}, \mathrm{I26} \\
(\mathrm{I} 7.0 \%)\end{array}$ & $\begin{array}{l}253,08 \mathrm{r} \\
(23.7 \%)\end{array}$ & Adopted \\
\hline $\begin{array}{l}\text { Authorizing exchange of } \\
\text { state lands for United } \\
\text { States lands }\end{array}$ & $\begin{array}{l}468,6 \mathrm{r} 7 \\
(44.0 \%)\end{array}$ & $\begin{array}{l}2 I 6,760 \\
(20.4 \%)\end{array}$ & $\begin{array}{l}378,955 \\
(35.6 \%)\end{array}$ & Not adopted \\
\hline $\begin{array}{l}\text { Limiting property of edu- } \\
\text { cational institutions, } \\
\text { for tax exemption pur- } \\
\text { poses, to that actually } \\
\text { used in institution }\end{array}$ & $\begin{array}{l}472,374 \\
(44.4 \%)\end{array}$ & $\begin{array}{l}247, \times 66 \\
(23.3 \%)\end{array}$ & $\begin{array}{c}344,792 \\
(32.3 \%)\end{array}$ & Not adopted \\
\hline $\begin{array}{l}\text { I936: Total vote } 1,164,268: \\
\text { Authorizing exchange of } \\
\text { state lands for United } \\
\text { State lands }\end{array}$ & $\begin{array}{l}448,917 \\
(38.6 \%)\end{array}$ & $\begin{array}{l}397, \text { I06 } \\
(34 . \mathrm{x} \%)\end{array}$ & $\begin{array}{c}318,245 \\
(27.3 \%)\end{array}$ & Not adopted \\
\hline $\begin{array}{l}\text { Changing tax system, au- } \\
\text { thorizing progressive } \\
\text { income tax, and other } \\
\text { taxes }^{9 x}\end{array}$ & $\begin{array}{l}355,588 \\
(30.6 \%)\end{array}$ & $\begin{array}{l}543,847 \\
(46.7 \%)\end{array}$ & $\begin{array}{l}264,833 \\
(22.7 \%)\end{array}$ & Defeated \\
\hline $\begin{array}{l}\text { I938: Total vote } \mathrm{I}, \mathrm{r} 44,926: \\
\text { Authorizing exchange of } \\
\text { state lands for United } \\
\text { State lands } 92\end{array}$ & $\begin{array}{l}609,046 \\
(53.0 \%)\end{array}$ & $\begin{array}{l}259,007 \\
(23.0 \%)\end{array}$ & $\begin{array}{l}276,873 \\
(24.0 \%)\end{array}$ & Adopted \\
\hline $\begin{array}{l}\text { Change of method for } \\
\text { adoptions of charters } \\
\text { for municipal corpora- } \\
\text { tions }\end{array}$ & $\begin{array}{l}488,370 \\
(42.7 \%)\end{array}$ & $\begin{array}{l}260,5_{52}^{2} \\
(22.7 \%)\end{array}$ & $\begin{array}{l}396,404 \\
(34.6 \%)\end{array}$ & Not adopted \\
\hline
\end{tabular}

90 Previously submitted in 1932.

${ }_{91}$ Tax amendments had previously been submitted in rgo2 and r920. A progressive income tax amendment was submitted in 1932, but it was not adopted although it received more affirmative than negative votes.

92 Previously submitted in $1930,1932,1934$, and 1936. 
amendments. ${ }^{93}$ Only twenty-three, or 30 per cent, were adopted, and the remainder, fifty-two in number constituting 67 per cent, even though they received preponderances of affirmative votes, failed of adoption. A further recapitulation of the data contained in the table is unnecessary to emphasize the unfortunate requirement that a constitutional amendment must secure a majority of the total vote. One can see many instances in which the affirmative vote was three or more times the negative vote and yet the proposal failed. In many cases the affirmative vote missed a majority of the total vote cast at the election by a very small margin.

Attention, however, will be directed specifically to two facts apparent from the table. First, how the severity of the requirement is mitigated somewhat in Minnesota by the power to lay an amendment before the voters repeatedly, until it happens to find the voters in a happy mood or until eventually sufficient interest has been aroused to obtain the required majority. ${ }^{94}$ Thus, a tax for a road and bridge fund was proposed five times, beginning in I902, before its adoption in I9Io, and in a different form in I9I2. Likewise, an amendment to permit the exchange of state land for United States land was adopted in I938, after having been placed before the people five times starting in r930. Other amendments adopted after repeated attempts were: an amendment to permit the investment of school funds by loans on improved farm land within the state, three times;

${ }_{93}$ The state-owned grain elevator amendment, proposed in 1924, and the progressive income tax amendment, proposed in 1936. The latter one had previously, in 1932, obtained a majority of the votes cast thereon, and yet failed. Other income tax amendments had failed of adoption in I902 and 1920 . The following election results complete Table 4:

\begin{tabular}{|c|c|c|c|c|}
\hline Year, etc. & Affirmative & Negative & Not Voting & Results \\
\hline $\begin{array}{l}\text { r94o: Total vote, } I, 301,573 \text { : } \\
\text { Changing requirements for publi- } \\
\text { cation of proposed amendments } \\
\text { to municipal charters }\end{array}$ & $\begin{array}{l}635,815 \\
(48.8 \%)\end{array}$ & $\begin{array}{l}287,286 \\
(22.0 \%)\end{array}$ & $\begin{array}{l}378,472 \\
(29.2 \%)\end{array}$ & Not adopted \\
\hline $\begin{array}{l}\text { I942: Total vote, } 817,511: \\
\text { Reducing rate of interest at which } \\
\text { state trust fund could be loaned }\end{array}$ & $\begin{array}{l}415, \text { or } 2 \\
(50.8 \%)\end{array}$ & $\begin{array}{l}190,563 \\
(23.3 \%)\end{array}$ & $\begin{array}{l}211,936 \\
(25.9 \%)\end{array}$ & Adopted \\
\hline $\begin{array}{l}\text { Reduce expense for publishing } \\
\text { amendments to home rule char- } \\
\text { ters }\end{array}$ & $\begin{array}{l}459,868 \\
(56.2 \%)\end{array}$ & $\begin{array}{l}144,842 \\
(17.7 \%)\end{array}$ & $\begin{array}{l}212,801 \\
(26.1 \%)\end{array}$ & Adopted \\
\hline
\end{tabular}

94 In Illinois amendments cannot be submitted to the same article of the constitution more frequently than once in four years. The "gateway" and revenue amendments have each been submitted more than once but they have not been adopted. Tllinois is further embarrassed, as far as attempts to amend its constitution are concerned, by the fact that amendments cannot be submitted to more than one article at any one general election. See Article XIV. Thus, an attempt to awaken interest in any particular amendment by submitting it more than once can only be made at the cost of neglecting other necessary amendments. Furthermore, it should also be remembered that in Minnesota amendments can be submitted to the voters by a mere majority of both houses of the legislature. Minn. Const., art. I4. Cf. Ill. Const., art. I4, which requires two-thirds of all the members elected to each of the two houses. 
an increase of the term of probate judges, three times; power to invest school funds in municipal bonds, three times.

Other amendments did not fare so well, notwithstanding repeated proposals. Three times the proposal that a system of reforestation be undertaken was thwarted; initiative and referendum proposals twice failed; a proposal providing for legislative reapportionment of the state failed in I9I0, I9I2, and I9I4; and several other proposals of less importance were not adopted after they had repeatedly received a preponderance of affirmative votes.

Of special importance is the failure to adopt most proposals to improve the state's tax system. Professor Anderson places emphasis upon this fact. ${ }^{95}$ True, the progressive income tax amendment was defeated by a proponderance of negative votes on the amendment, but that was after the same proposal had received more affirmative than negative votes in I932 and yet was not adopted, and after similar proposals had met the same fate in I 902 and I920. At least five other measures to reform the taxing system of the state failed of adoption, although favored by a preponderance of those voting on the propositions.

Minnesota has never had any system whereby political party action concerning proposed amendments could be printed upon the official ballot, and all party circle votes counted accordingly..$^{96}$ Prior to I903 proposed amendments were placed at the bottom of the official ballot.97 In I903 a statute was passed requiring all proposed amendments to be submitted to the voters upon a separate pink ballot, as distinguished from the ballot with the names of the candidates, which is white. ${ }^{98}$ At the I94I session of the legislature a law was passed requiring that the following statement appear upon the separate ballot for constitutional amendments: "If a voter fails to vote, he votes in effect, in the negative." Mr. M. Holm, Secretary of State of Minnesota, reported that such a statement will be printed upon the next ballot upon which constitutional amendments are submitted. 99

It will be interesting to compare the percentage of general election voters who voted one way or the other on proposed amendments before the change in the method of amending, with the percentage who voted after the change (see Table 5). For convenience in making comparisons, five groups of amendments have been selected: I) Those on which 20 per

95 Anderson, op. cit. supra note 8 at $203-5$.

97 Minn. L. ( 1893 ) c. 4 .

${ }_{96}^{6}$ Note 74 supra.

${ }_{98}^{8}$ Minn. L. (1903) c. 25 r.

$99 \mathrm{He}$ also wrote: "I have no doubt but what it will improve greatly the chances of adoption of a proposal." This device is not to be confused with that used at one time in Alabama. The Alabama system actually counted as affirmative votes all not cast in the negative. Minnesota merely intends to call the voters' attention to the effect of a failure to vote upon proposed amendments. 
TABLE $5^{\text {I00 }}$

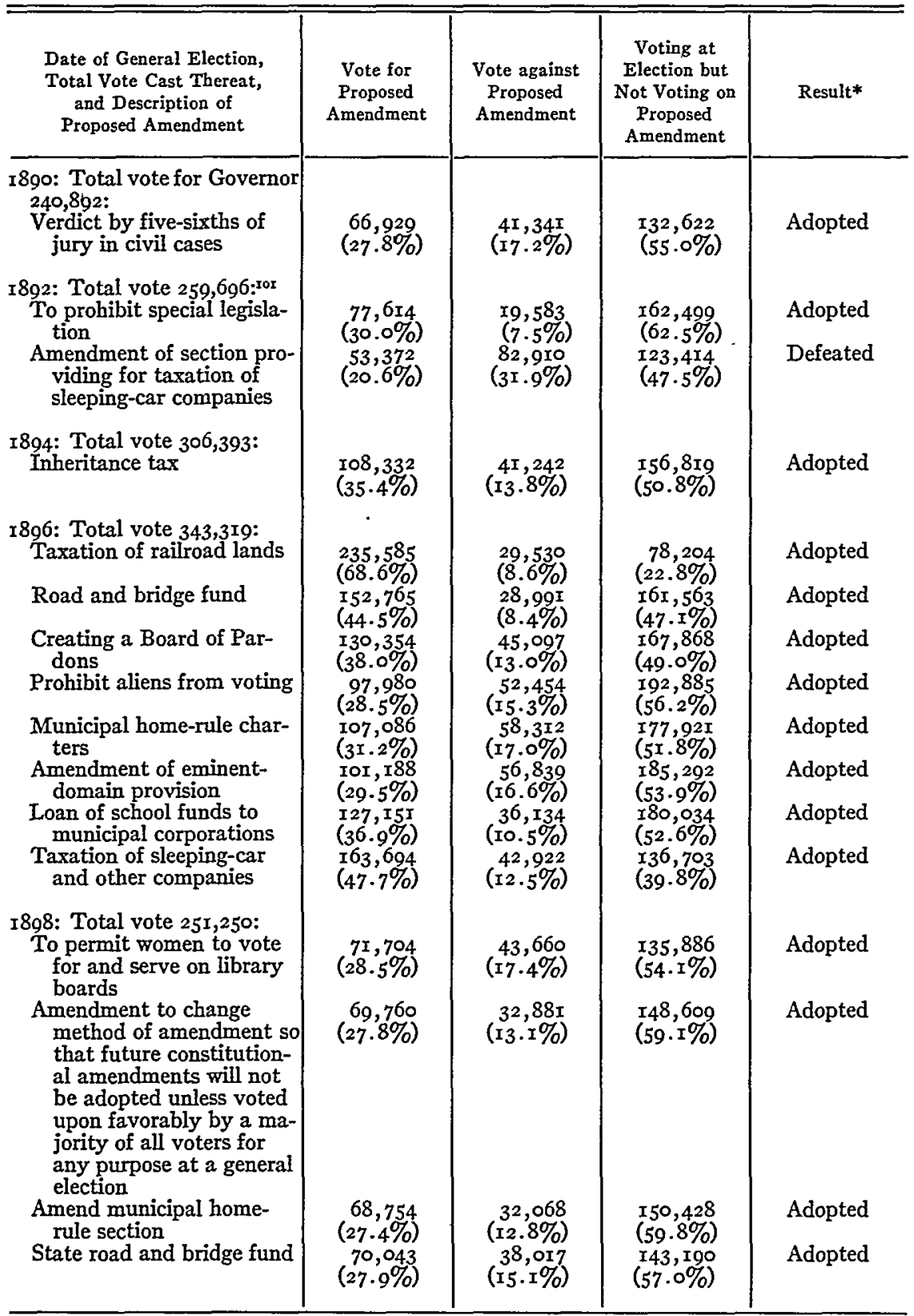

* Remember that at this time the amendment carried if more voted yes than no, irrespective of the total vote at the election.

${ }^{100}$ The following table is a record of the amendments proposed to the voters of Minnesota between $189 \circ$ and 1898 , inclusive. The information was obtained from Mr. M. Holm, Secretary of State of Minnesota, supplemented by Anderson and Lobb, op. cit. supra note 76 .

sor Total vote of four political parties for members of congress. The total vote at the election may have been slightly larger than this figure. 
cent or less of the general election voters voted one way or the other; 2) where the percentage was between $2 \mathrm{I}$ and 40 inclusive; 3) where the percentage was between $4 \mathrm{I}$ and 60 inclusive; 4) where the percentage was between $6 \mathrm{I}$ and 80 inclusive; and 5) where the percentage was $8 \mathrm{I}$ or over. For this purpose there are three significant periods. From 1890 to 1898 inclusive, amendments were ratified by a majority voting thereon, irrespective of the number who voted at the general election, and the amendments appeared at the foot of the ballot upon which the names of the candidates for office appeared. After 1898 , a proposed amendment must obtain a majority of all voting for any purpose at a general election in order to be ratified; but the ballot upon which the proposal was submitted remained the same. In I9O3 the present system of submitting proposed amendments upon a separate pink ballot was adopted. This comparison is exhibited in Table 6.

TABLE 6

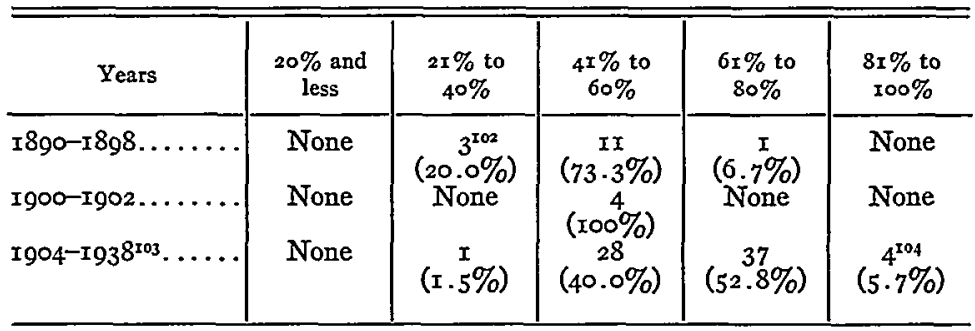

From Table 6 it appears that there was no substantial change in the percentage figure of those who voted on proposed amendments after the change in the system of amendment in 1898 , until the adoption of a separate ballot of a different color, in I903. If it be suggested that during the lapse of thirty-four years between I904 and $x 938$ the increase in popular education may have caused a larger portion of the voters to become interested in constitutional reform, it may be observed that the change in the percentage voting upon proposed amendments was immediate upon the change in the form of the ballot in I 903 . Four of the five propositions voted upon in 1904 and 1906 attracted a vote of more than 70 per cent of the total vote cast in the general elections for those years.

ro: These percentages are the percentage of the total number of amendments submitted.

${ }^{103}$ These figures will add up to seventy rather than seventy-two (seventy-six constitutes the total number of amendments proposed since I900, minus four considered in the I900-I902 category) because data as to the total vote in 1922 is not available.

104 The four amendments which attracted a vote of more than 80 per cent of that cast at the general election were: Prohibition in 1918, and three amendments in 1920 , 1924, and 1928 proposing various methods of financing a proposed truck highway system for the state. It is interesting to note that three of these four were adopted. 
Further comparison may be made with the percentage of votes cast upon constitutional amendments in Illinois and New York (see Table 7).

It is evident that since I903, a larger percentage of those voting at general elections in Minnesota have voted upon proposed constitutional amendments than in either Mlinois or New York. It is a reasonable inference that the separate ballot is responsible for this increase. This conclusion is supported by the fact that of six constitutional propositions submitted in Illinois between 1899 and 1929 , while constitutional propositions were submitted upon a ballot distinct from that carrying the names of the candidates for office, four were voted upon by more than 60 per cent of the voters who voted at the elections at which they were submitted.

TABLE $7^{\text {ros }}$

\begin{tabular}{|c|c|c|c|c|}
\hline $20 \%$ and under & $\begin{array}{c}2 \times \% \text { to } \\
40 \%\end{array}$ & $\begin{array}{c}4 \mathrm{r} \% \text { to } \\
60 \%\end{array}$ & $\begin{array}{c}6 \mathrm{x} \% \text { to } \\
80 \%\end{array}$ & $\begin{array}{c}8 \mathrm{r} \% \text { and } \\
\text { over }\end{array}$ \\
\hline 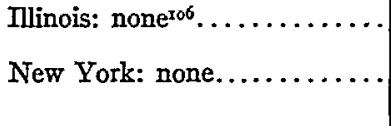 & $\begin{array}{c}6 \\
(42.8 \%) \\
10 \\
(40.0 \%)\end{array}$ & $\begin{array}{c}4 \\
(28.6 \%) \\
14 \\
(56.0 \%)\end{array}$ & $\begin{array}{c}4 \\
(28.6 \%) \\
I \\
(4.0 \%)\end{array}$ & $\begin{array}{l}\text { None } \\
\text { None }\end{array}$ \\
\hline
\end{tabular}

Mississippi-Table 8 shows the constitutional amendments submitted to the voters of Mississippi since $I 898$.

A summary of this table shows that since 1898 the electorate of Mississippi has voted forty-four times upon thirty-three proposals for amendments to the state constitution. In twenty-three of the fortyfour instances the proposed amendments were adopted. In nine they were defeated by a preponderance of negative votes. In twelve, more affirmative than negative votes were cast upon the proposed amendments, but they were not adopted because they failed to obtain a majority of all votes cast at the general election. Of the thirty-three proposed amendments, fifteen were adopted the first time voted upon, seven were defeated the first time voted upon by a preponderance of negative votes upon the proposals, and eleven secured a favorable majority of those voting upon the proposals but were not adopted

${ }^{105}$ The Illinois data is contained in Table I. The New York data is taken from the tables in Sears, op. cit. supra note 49 at 245,248 . The table on page 245 is the New York vote upon amendments submitted by a convention in 1938 . The table on page 248 contains the vote on certain proposed constitutional amendments between $x_{929}$ and 1937 , inclusive.

${ }^{106}$ The Illinois figures cover constitutional propositions after $189 x$. Prior to $189 x$, which was the year of the adoption of the Australian ballot in Illinois, party tickets frequently took positions upon constitutional propositions. Unscratched party votes were counted according to the party positions. Prior to I89I, all five of the amendments proposed received more than 60 per cent of the vote cast at the general election at which they were submitted, and two received more than 80 per cent. 
TABLE $8^{\mathrm{ro7}}$

\begin{tabular}{|c|c|c|c|c|}
\hline $\begin{array}{l}\text { Year, Total Vote Cast } \\
\text { at Election, and Description } \\
\text { of Proposed Amendment }\end{array}$ & $\begin{array}{l}\text { Vote for } \\
\text { Proposed } \\
\text { Amendment }\end{array}$ & $\begin{array}{l}\text { Vote against } \\
\text { Proposed } \\
\text { Amendment }\end{array}$ & $\begin{array}{l}\text { Voting at } \\
\text { Election but } \\
\text { Not Voting for } \\
\text { or against } \\
\text { Proposed } \\
\text { Amendment }\end{array}$ & Result \\
\hline $\begin{array}{l}\text { I898: Total vote } 27,378: \\
\text { To give additional powers } \\
\text { to commissioners of } \\
\text { levee districts }\end{array}$ & $\begin{array}{l}I 4,516 \\
(53.0 \%)\end{array}$ & $\begin{array}{c}5,32 I \\
(19.5 \%)\end{array}$ & $\begin{array}{c}7,54 \mathrm{I} \\
(27.5 \%)\end{array}$ & Adopted \\
\hline $\begin{array}{l}\text { Igoo: Total vote not ap- } \\
\text { parent: } \\
\text { Reorganization of su- } \\
\text { preme court }\end{array}$ & $2 x, 169$ & 8,643 & $\ldots \ldots \ldots \ldots$ & Adopted \\
\hline $\begin{array}{l}\text { 1902: Total vote } 18, \circ 72: \\
\text { To forbid counties and } \\
\text { municipalities from } \\
\text { holding stock in or aid- } \\
\text { ino corporations }\end{array}$ & $\begin{array}{c}7,665 \\
(42.4 \%)\end{array}$ & $\begin{array}{c}7,464 \\
(4 \mathbf{1}-4 \%)\end{array}$ & $\begin{array}{r}2,943 \\
( \pm 6.2 \%)\end{array}$ & Not adopted \\
\hline $\begin{array}{l}\text { ing corporations } \\
\text { To change method of } \\
\text { amendment to permit } \\
\text { ratification of proposed } \\
\text { amendment by major- }\end{array}$ & $\begin{array}{c}7,354 \\
(40.7 \%)\end{array}$ & $\begin{array}{c}7,427 \\
(4 \mathrm{r} . \mathrm{x} \%)\end{array}$ & $\begin{array}{c}3,29 I \\
(18.2 \%)\end{array}$ & Defeated \\
\hline $\begin{array}{l}\text { ity voting upon issue } \\
\text { To require meeting of } \\
\text { legislature every two } \\
\text { years }\end{array}$ & $\begin{array}{c}8,088 \\
(44.8 \%)\end{array}$ & $\begin{array}{c}6,602 \\
(36.6 \%)\end{array}$ & $\begin{array}{c}3,382 \\
(\mathbf{8} 8.6 \%)\end{array}$ & Not adopted \\
\hline $\begin{array}{l}\text { I9I0: Total vote } 25,888: \\
\text { To require meeting of } \\
\text { legislature every two } \\
\text { years }{ }^{\text {ros }}\end{array}$ & $\begin{array}{c}20,362 \\
(80.0 \%)\end{array}$ & $\begin{array}{c}3,987 \\
(\mathbf{x} .9 \%)\end{array}$ & $\begin{array}{c}\mathbf{I}, 539 \\
(5.1 \%)\end{array}$ & Adopted \\
\hline $\begin{array}{l}\text { Popular election of cir- } \\
\text { cuit and chancery }\end{array}$ & $\begin{array}{l}19,597 \\
(76.0 \%)\end{array}$ & $\begin{array}{c}5, I_{59} \\
(20.0 \%)\end{array}$ & $\begin{array}{c}\mathrm{I}, \mathrm{I} 32 \\
(4.0 \%)\end{array}$ & Adopted \\
\hline $\begin{array}{l}\text { court judges } \\
\text { That every proposed } \\
\text { amendment be adopt- } \\
\text { ed by the legislature at } \\
\text { the next session after } \\
\text { adoption by popular } \\
\text { vote }\end{array}$ & $\begin{array}{l}\text { I9,013 } \\
(73.5 \%)\end{array}$ & $\begin{array}{c}4,036 \\
(15 \cdot 5 \%)\end{array}$ & $\begin{array}{c}2,839 \\
(\mathrm{x} .0 \%)\end{array}$ & Adopted \\
\hline $\begin{array}{l}\text { I9I2: Total vote } 64,948 \text { : } \\
\text { Prescribing the manner } \\
\text { by which bills should } \\
\text { be introduced into the } \\
\text { legislature }\end{array}$ & $\begin{array}{c}27,8 \mathrm{r} 8 \\
(43.0 \%)\end{array}$ & $\begin{array}{l}13,594 \\
(20.8 \%)\end{array}$ & $\begin{array}{c}23,536 \\
(36.2 \%)\end{array}$ & Not adopted \\
\hline $\begin{array}{l}\text { To permit verdicts in } \\
\text { civil cases by the con- } \\
\text { currence of nine out of } \\
\text { twelve jurors }\end{array}$ & $\begin{array}{l}28,064 \\
(43.2 \%)\end{array}$ & $\begin{array}{l}14,255 \\
(21.8 \%)\end{array}$ & $\begin{array}{c}22,629 \\
(35.0 \%)\end{array}$ & Not adopted \\
\hline $\begin{array}{l}\text { twelve jurors } \\
\text { Initiative and referen- } \\
\text { dum }\end{array}$ & $\begin{array}{r}25,153 \\
(38.8 \%)\end{array}$ & $\begin{array}{c}13,383 \\
(20.5 \%)\end{array}$ & $\begin{array}{c}26,4 \mathrm{Ir} 2 \\
(40.7 \%)\end{array}$ & Not adopted \\
\hline
\end{tabular}

${ }^{107}$ This data was obtained by searching the files in the office of the Secretary of State of Mississippi. This search was made possible through the courtesy of Mr. Wood, Secretary of State of Mississippi, and has been checked as far as possible with the Mississippi official reports.

${ }^{208}$ Same amendment submitted in 1902. 
TABLE 8-Continued

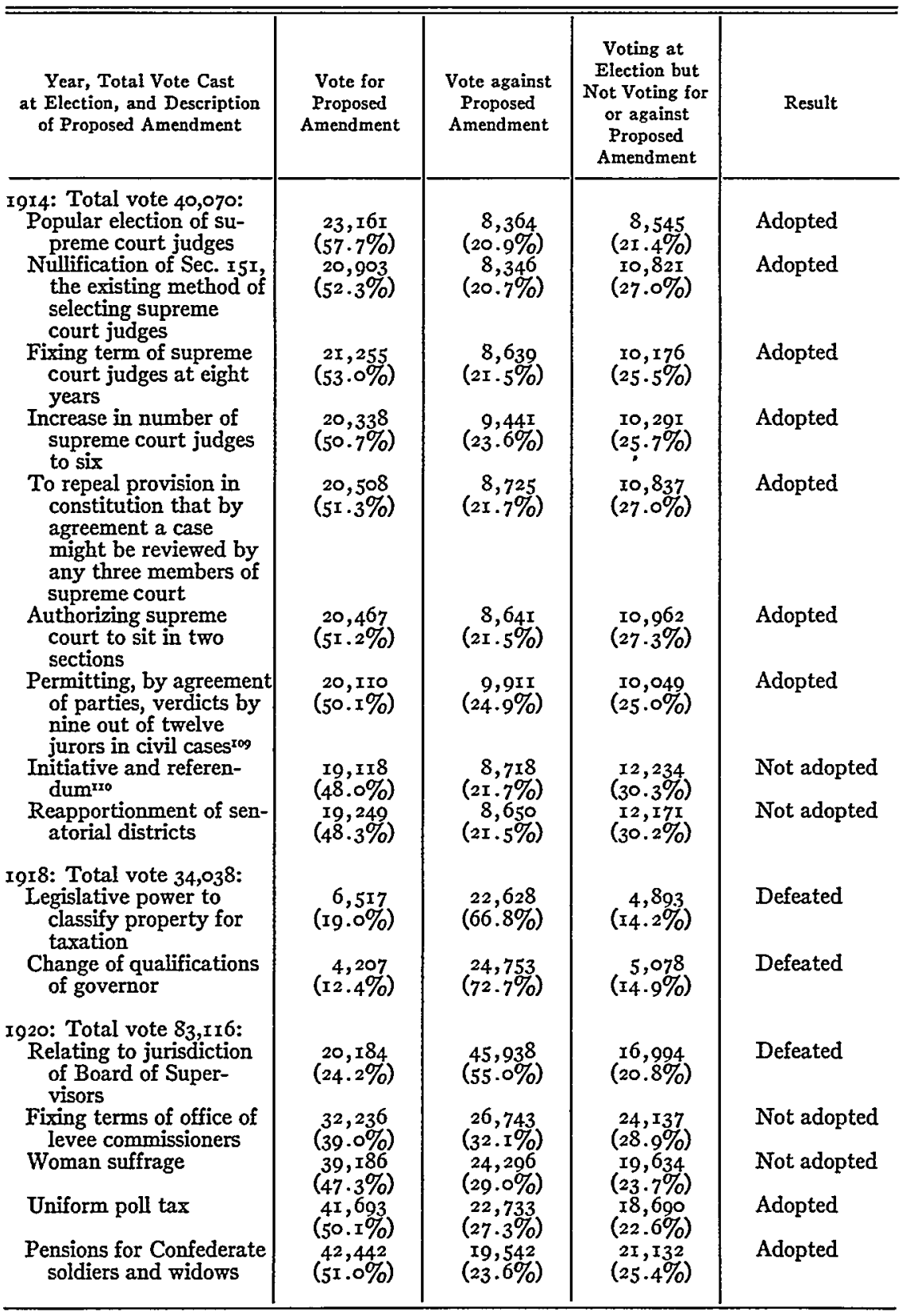

ro9 Same amendment submitted in rgr2.

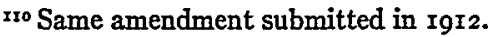


TABLE 8-Contimued

\begin{tabular}{|c|c|c|c|c|}
\hline $\begin{array}{l}\text { Year, Total Vote Cast } \\
\text { at Election, and Description } \\
\text { of Proposed Amendment }\end{array}$ & $\begin{array}{l}\text { Vote for } \\
\text { Proposed } \\
\text { Amendment }\end{array}$ & $\begin{array}{l}\text { Vote against } \\
\text { Proposed } \\
\text { Amendment }\end{array}$ & $\begin{array}{l}\text { Voting at } \\
\text { Election but } \\
\text { Not Voting for } \\
\text { or against } \\
\text { Proposed } \\
\text { Amendment }\end{array}$ & Result \\
\hline $\begin{array}{l}\text { r922: Tqtal vote } 71,835: \\
\text { To abolish office of } \\
\text { county treasurer }\end{array}$ & $46,47 x$ & I5, 380 & 9,984 & Adopted \\
\hline $\begin{array}{l}\text { Relating to jurisdiction } \\
\text { of Board of Super- } \\
\text { visors }\end{array}$ & $\begin{array}{c}(04.7 \% \text { ) } \\
53,792 \\
(75.0 \%)\end{array}$ & $\begin{array}{l}\text { (2x. } 1 \%, 465 \\
\text { (I4.5\%) }\end{array}$ & $\begin{array}{c}(I 4.2 \%) \\
7,578 \\
(10.5 \%)\end{array}$ & Adopted \\
\hline $\begin{array}{l}\text { 1924: Total vote II8,327: } \\
\text { Progressive Income and } \\
\text { inheritance taxes }\end{array}$ & $\begin{array}{l}9,865 \\
(8.4 \%)\end{array}$ & $\begin{array}{c}83,689 \\
(71.0 \%)\end{array}$ & $\begin{array}{c}24,773 \\
(20.6 \%)\end{array}$ & Defeated \\
\hline $\begin{array}{l}\text { To fix number of levee } \\
\text { commissioners in each } \\
\text { district }\end{array}$ & $\begin{array}{c}33,932 \\
(28.7 \%)\end{array}$ & $\begin{array}{c}5 \circ, 463 \\
(42.6 \%)\end{array}$ & $\begin{array}{l}33,932 \\
(28.7 \%)\end{array}$ & Defeated \\
\hline $\begin{array}{l}\text { To change manner of } \\
\text { electing levee commis- } \\
\text { missioners }\end{array}$ & $\begin{array}{l}33,992 \\
(28.7 \%)\end{array}$ & $\begin{array}{c}45,808 \\
(38.7 \%)\end{array}$ & $\begin{array}{c}38,527 \\
(32.6 \%)\end{array}$ & Defeated \\
\hline $\begin{array}{l}\text { I926: Total vote } 29,485: \\
\text { To fix number of levee } \\
\text { commissioners in each } \\
\text { district }{ }^{152}\end{array}$ & $\begin{array}{c}24,83 x \\
(84.1 \%)\end{array}$ & $\begin{array}{c}978 \\
(3.3 \%)\end{array}$ & $\begin{array}{r}3,676 \\
\text { (I2.6\%) }\end{array}$ & Adopted \\
\hline $\begin{array}{l}\text { To change manner of } \\
\text { electing levee commis- } \\
\text { sioners and to fix their } \\
\text { terms of office }\end{array}$ & $\begin{array}{c}25,185 \\
(85.7 \%)\end{array}$ & $\begin{array}{l}I, 004 \\
(3.3 \%)\end{array}$ & $\begin{array}{c}3,296 \\
(\mathrm{x} .0 \%)\end{array}$ & Adopted \\
\hline $\begin{array}{l}\text { 1932: Total vote I46,029: } \\
\text { To change beginning of } \\
\text { fiscal year from Oc- } \\
\text { tober I to July I }\end{array}$ & $\begin{array}{c}62,026 \\
(42.5 \%)\end{array}$ & $\begin{array}{r}21,230 \\
(14.5 \%\end{array}$ & $\begin{array}{c}62,773 \\
(43.0 \%)\end{array}$ & Not adopted \\
\hline $\begin{array}{l}\text { Appropriation laws to } \\
\text { have no validity after } \\
\text { two months after end } \\
\text { of fiscal year follow- } \\
\text { ing year of passage }\end{array}$ & $\begin{array}{l}55,243 \\
(37.8 \%)\end{array}$ & $\begin{array}{c}2 \mathrm{I}, 37 \mathrm{I} \\
(\mathrm{I} 4.5 \%)\end{array}$ & $\begin{array}{c}69,415 \\
(47.7 \%)\end{array}$ & Not adopted \\
\hline $\begin{array}{l}\text { Payment of poll tax to } \\
\text { be only qualification } \\
\text { for suffrage }\end{array}$ & $\begin{array}{c}68,202 \\
(46.7 \%)\end{array}$ & $\begin{array}{l}23,710 \\
(16.2 \%)\end{array}$ & $\begin{array}{l}54, \mathrm{xx7} \\
(37 . \mathrm{r} \%)\end{array}$ & Not adopted \\
\hline $\begin{array}{l}\text { Age at which children } \\
\text { must attend school } \\
\text { changed from five to } \\
\text { six }\end{array}$ & $\begin{array}{c}73,966 \\
(50.5 \%)\end{array}$ & $\begin{array}{l}2 \mathrm{I}, 4 \mathrm{I} 2 \\
(\mathrm{I} 4.7 \%)\end{array}$ & $\begin{array}{l}50,65 \mathrm{I} \\
(34.8 \%)\end{array}$ & Adopted \\
\hline $\begin{array}{l}\text { Progressive income and } \\
\text { inheritance taxes }\end{array}$ & $\begin{array}{l}38,648 \\
(26.4 \%)\end{array}$ & $\begin{array}{l}4 \mathrm{r}, \mathrm{r} 8 \mathrm{o} \\
(28.2 \%)\end{array}$ & $\begin{array}{l}66,20 I \\
(45.4 \%)\end{array}$ & Defeated \\
\hline
\end{tabular}

Ix Same amendment submitted in 1920.

112 Same amendment submitted in I924.

${ }_{1 \times 3}$ Combined subject matter of amendment submitted in r92o but not adopted and one submitted in I924 but defeated. 
TABLE 8-Continued

\begin{tabular}{|c|c|c|c|c|}
\hline $\begin{array}{l}\text { Year, Total Vote Cast } \\
\text { at Election, and Description } \\
\text { of Proposed Amendment }\end{array}$ & $\begin{array}{l}\text { Vote for } \\
\text { Proposed } \\
\text { Amendment }\end{array}$ & $\begin{array}{l}\text { Vote against } \\
\text { Proposed } \\
\text { Amendment }\end{array}$ & $\begin{array}{l}\text { Voting at } \\
\text { Election but } \\
\text { not Voting for } \\
\text { or against } \\
\text { Proposed } \\
\text { Amendment }\end{array}$ & Result \\
\hline $\begin{array}{l}\text { I934: Total vote } 58,419: \\
\text { Payment of poll tax to be } \\
\text { only qualification for } \\
\text { suffrage }\end{array}$ & $\begin{array}{l}39,427 \\
(67.5 \%)\end{array}$ & $\begin{array}{c}\mathrm{I3}, \mathrm{II} 3 \\
(22.4 \%)\end{array}$ & $\begin{array}{r}5,879 \\
(\text { Iо.x\%) }\end{array}$ & Adopted \\
\hline $\begin{array}{l}\text { To change beginning of } \\
\text { fiscal year from Octo- } \\
\text { ber I to July I Irs }\end{array}$ & $\begin{array}{l}34,033 \\
\left(5^{8} .3 \%\right)\end{array}$ & $\begin{array}{c}15, \text { or } 7 \\
(25.7 \%)\end{array}$ & $\begin{array}{c}9,369 \\
(16.0 \%)\end{array}$ & Adopted \\
\hline $\begin{array}{l}\text { Appropriation laws to } \\
\text { have no validity after } \\
\text { two months after end } \\
\text { of fiscal year following } \\
\text { year of passage }\end{array}$ & $\begin{array}{l}30,907 \\
(53.0 \%)\end{array}$ & $\begin{array}{l}16,636 \\
(28.5 \%)\end{array}$ & $\begin{array}{l}\text { Io, } 876 \\
(18.5 \%)\end{array}$ & Adopted \\
\hline $\begin{array}{l}\text { Progressive income and } \\
\text { inheritance taxes }\end{array}$ & $\begin{array}{c}9,833 \\
(16.8 \%)\end{array}$ & $\begin{array}{c}38,695 \\
(66.2 \%)\end{array}$ & $\begin{array}{c}9,89 \mathrm{r} \\
(\mathrm{r} 7.0 \%)\end{array}$ & Defeated \\
\hline $\begin{array}{l}\text { I940: Total vote } 168,267 \text { : } \\
\text { Allowing state to sell } \\
\text { certain land owned } \\
\text { by it }\end{array}$ & $\begin{array}{l}\text { II } 7,5 \text { I9 } \\
(69.5 \%)\end{array}$ & $\begin{array}{l}\mathrm{I} 4, \mathrm{Ig6} \\
(8.4 \%)\end{array}$ & $\begin{array}{c}36,552 \\
(22.1 \%)\end{array}$ & Adopted 118 \\
\hline
\end{tabular}

because they failed to obtain a majority of all votes cast for any purpose at the general election at which they were submitted to the voters. Of the latter eleven, four were not again submitted to the voters but seven were voted upon again. Of the seven submitted to the voters the second time, six were adopted, and one, the initiative and referendum proposal of I9I2, again failed of adoption in I9I4, although both times more votes were cast for it than against it. ${ }^{119}$ Thus, in five out of thirty-three distinct amendments the desire of a majority of the people sufficiently interested to vote was thwarted, four times because the previously proposed amend-

${ }^{114}$ Same amendment submitted in $1932 . \quad{ }^{116}$ Ibid.

Is Ibid.

${ }^{117}$ Same amendment defeated in 1924 and $193^{2}$.

${ }^{118}$ The following election returns complete Table 7:

\begin{tabular}{l|c|c|c|c}
\hline & Affrmative & Negative & Not Voting & Results \\
\hline $\begin{array}{c}\text { 1942: Total vote 52,0.5: } \\
\text { Cration of board of trustees of } \\
\text { state schools }\end{array}$ & $\begin{array}{c}44,785 \\
(86 . x \%)\end{array}$ & $\begin{array}{c}4,250 \\
(8.2 \%)\end{array}$ & $\begin{array}{c}3, \text { oro } \\
(5.7 \%)\end{array}$ & Adopted \\
$\begin{array}{c}\text { Providing for lease of township } \\
\text { school land }\end{array}$ & $\begin{array}{c}42,750 \\
(82.1 \%)\end{array}$ & $\begin{array}{c}5,378 \\
(10.2 \%)\end{array}$ & $\begin{array}{c}3,91 \% \\
(7.7 \%)\end{array}$ & Adopted \\
\hline
\end{tabular}

${ }^{119}$ Of the seven defeated the first time they were submitted, by a preponderance of negative votes upon the proposals themselves, three were abandoned, and four were again submitted. Of these four, three were later adopted. The amendment to authorize income and inheritance tax laws was defeated three times, in I924, 1932, and 1934. 
ments were not again proposed and once because it was again proposed and again failed.

The ballot used in the general elections of Mississippi contains several columns but not party columns. At the top of the left-hand column are the candidates for the most important office. Thereunder other offices and candidates are listed. After these offices, and the candidates therefor, the proposed amendments are listed. The amendments usually start about halfway down the second column, and generally run over into the third column. Thus amendments are partially at the bottom and partially at the right of the ballot. The texts of all proposed amendments are set out in full rather than being summarized as in Minnesota and most states. ${ }^{\text {T20 }}$ The record for participation by general election voters, in the vote upon proposed amendments, is particularly good. Out of forty-three amendments voted upon, ${ }^{\mathrm{Ixx}}$ twenty-four, or 55 per cent, were voted upon by between $6 \mathrm{I}$ and 80 .per cent of those voting in the general election; and fifteen, or 33 per cent, were voted upon by more than 80 per cent of those voting at the general election. Only four amendments were voted upon by less than 60 per cent of the voters voting at the general election and none was voted upon by less than 40 per cent. ${ }^{\mathrm{I22}}$

The Mississippi record of constitutional amendment is good when compared with that of Minnesota and Illinois. Such a view accords with that expressed by one versed in governmental affairs in that state. ${ }^{\text {I23 }}$ It must be remembered that the southern states have a select electorate, which probably has a greater interest in constitutional problems than is felt in the case of the average electorate in the northern states. Furthermore, Mississippi's record would not look at all good were it not for the feasibility of resubmitting an amendment which failed to obtain ratification. In Tennessee and Mllinois ${ }^{22}$ such an expedient is not as readily available because of limitations upon the number and frequency with which amendments may be submitted for ratification. $\dagger$

${ }^{120}$ Information furnished through private correspondence with Mr. W. Wood, Secretary of State of Mississippi.

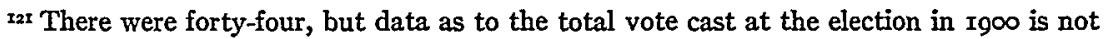
available.

122 Figures apparent from Table 7.

${ }^{123}$ Professor H. B. Howerton, head of the Department of Political Science in the University of Mississippi, has stated, in a private letter, that the people of Mississippi are well satisfied with their ability to amend their constitution. He states: "We have had five or six amendments ratified in the past few years. It is true we have had two or three defeated, but my judgment is that we are able to amend the Constitution of Mississippi without a great deal of trouble, provided of course the subject matter is of potential general interest."

${ }^{124}$ See Tenn. Const. art. $\mathrm{r}, \S 3$ and $\mathrm{ml}$. Const. art. $\mathrm{x}_{4}$.

$\dagger$ This article will be concluded in a forthcoming issue of the Review. 